Review

\title{
New Strategies and Combinations to Improve Outcomes in Immunotherapy in Metastatic Non-Small-Cell Lung Cancer
}

\author{
Lucy Corke ${ }^{1}$ and Adrian Sacher ${ }^{1,2, *}$ \\ 1 Princess Margaret Cancer Centre, University Health Network, Toronto, ON M5G 2C1, Canada; \\ lucy.corke@uhn.ca \\ 2 Department of Immunology, University of Toronto, Toronto, ON M5S 1A1, Canada \\ * Correspondence: adrian.sacher@uhn.ca
}

check for updates

Citation: Corke, L.; Sacher, A. New Strategies and Combinations to Improve Outcomes in Immunotherapy in Metastatic Non-Small-Cell Lung Cancer. Curr. Oncol. 2022, 29, 38-55. https:// doi.org/10.3390/curroncol29010004

Received: 1 October 2021

Accepted: 8 December 2021

Published: 23 December 2021

Publisher's Note: MDPI stays neutral with regard to jurisdictional claims in published maps and institutional affiliations.

Copyright: (C) 2021 by the authors. Licensee MDPI, Basel, Switzerland. This article is an open access article distributed under the terms and conditions of the Creative Commons Attribution (CC BY) license (https:// creativecommons.org/licenses/by/ $4.0 /)$.

\begin{abstract}
Immune checkpoint inhibitors have transformed the treatment of metastatic non-smallcell lung cancer, yielding marked improvements in survival and the potential for durable clinical responses. Primary and acquired resistance to current immune checkpoint inhibitors constitute a key challenge despite the remarkable responses observed in a subset of patients. Multiple novel combination immunotherapy and adoptive cell therapy strategies are presently being developed to address treatment resistance. The success of these strategies hinges upon rational clinical trial design as well as careful consideration of the immunologic mechanisms within the variable tumor immune microenvironment (TIME) which underpin resistance to immunotherapy. Further research is needed to facilitate a deeper understanding of these complex mechanisms within the TIME, which may ultimately provide the key to restoring and enhancing an effective anti-tumor immune response. This review aims to provide an introduction to some of the recent and notable combination immunotherapy and cell therapy strategies used in advanced non-small-cell lung cancer (NSCLC), and the rationale for their use based on current understanding of the anti-tumor immune response and mechanisms of resistance within the TIME.
\end{abstract}

Keywords: non-small-cell lung cancer; immunotherapy; tumor microenvironment

\section{Introduction}

Lung cancer is the leading cause of cancer-related death worldwide. Immune checkpoint inhibitors have revolutionized the treatment of metastatic non-small-cell lung cancer (mNSCLC), with marked improvement in overall survival and the potential for durable clinical benefit. However, long-term disease control is only seen in approximately $15-20 \%$ of patients and extensive investigation has yet to yield a definitive biomarker of durable response to existing immunotherapies [1]. There is growing understanding that the environment in which tumor and immune cells interact (the tumor immune microenvironment (TIME)) is crucial in determining therapeutic outcomes. Furthermore, improved understanding of the myriad complex interactions of immune, tumor and stromal cells within the TIME and draining lymph nodes has the potential to guide the rational development of novel immunotherapeutic combinations as well as identify mechanisms of primary and acquired resistance to existing immunotherapies. This review will utilize our current understanding of the TIME and the mechanisms involved in the induction of an effective anti-tumor immune response as a framework to understand the rationale as well as potential of novel combination immunotherapeutic and cell therapy strategies in mNSCLC.

\section{The Tumor Immune Microenvironment (TIME)}

The TIME represents a highly variable environment composed of multiple immune cell populations as well as stromal and tumor cells. Its composition reflects the complex interplay between the tumor and the immune system, offering a unique insight into the degree to which a functional immune response exists in a given tumor. T cells and natural 
killer (NK) cells are classically regarded as the primary workhorses of anti-tumor immunity, as their priming and activation are critical for anti-tumor response. Complex interactions exist between these and other immune cell populations, tumor and stromal cells, which all work to resist or promote the overall response (Figure 1).

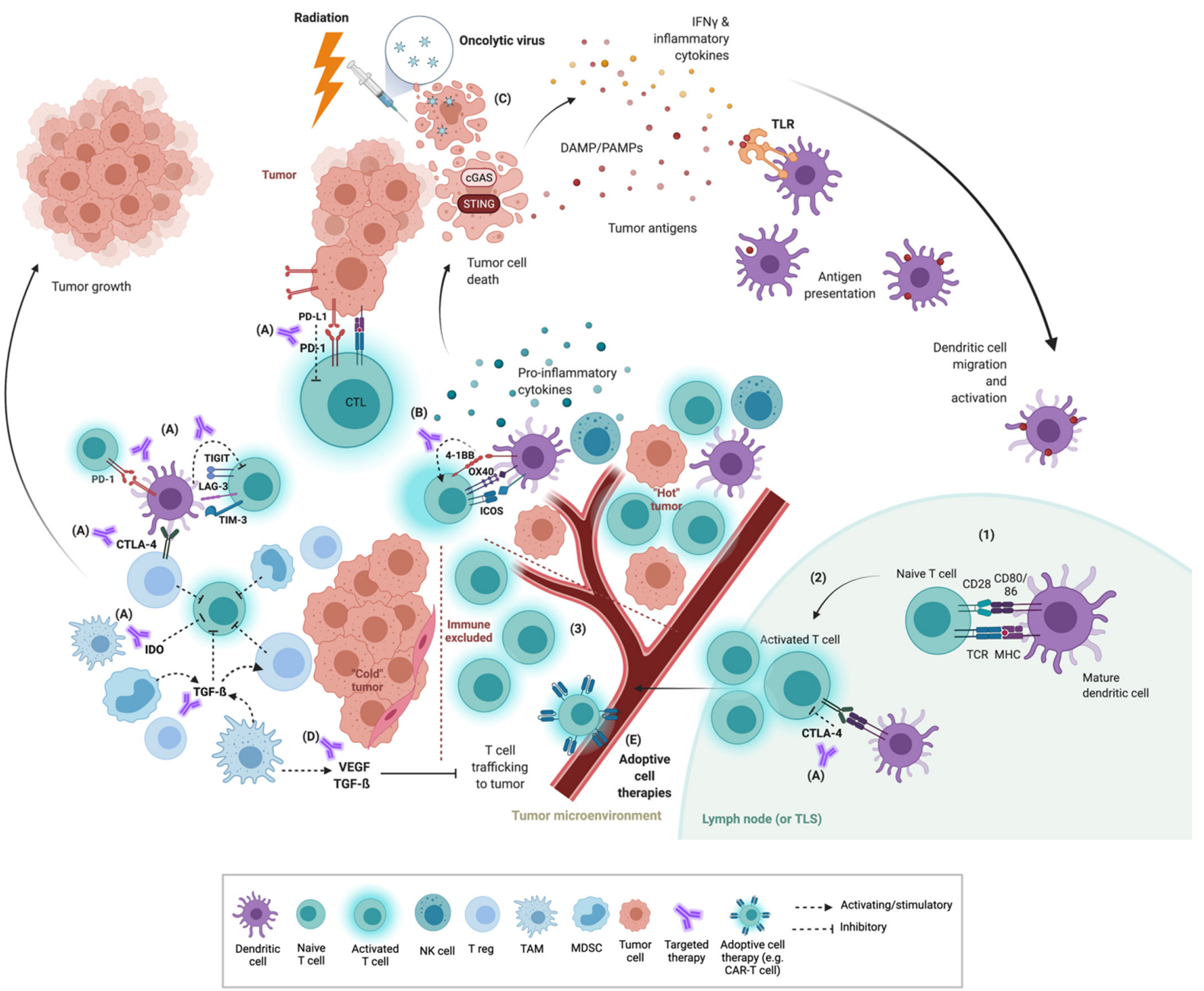

Figure 1. T-cell tumor response and interactions within the tumor immune microenvironment (TIME). Priming of $\mathrm{T}$ cells begins with presentation of tumor antigen to naïve $\mathrm{T}$ cells via antigen-presenting cells within draining lymph nodes (and potentially in tumor lymphoid structures, TLS) (1). Activation occurs when T-cell receptors (TCR) recognize their specific peptide antigen presented by MHC and in the presence of co-stimulation signaling between CD28 and CD80/86, with additional co-stimulation from inflammatory cytokines (2). Activated T cells undergo expansion and then traffic to the tumor where they can engage in direct cytotoxicity against tumor cells presenting cognate antigen via MHC. Tumor immune microenvironments can be conceptualised as "hot", "cold" or "immune excluded" (3). "Hot" or inflamed TIME contain abundant CTLs and other immune cell populations (dendritic cells, NK cells) associated with anti-tumor immunity and expression of inhibitory checkpoints, and thus are more likely to respond to checkpoint inhibition resulting in tumor cell death. "Cold" tumors by contrast contain more immunosuppressive cell populations such as Tregs, TAMs, MDSCs. Immuneexcluded tumors contain inflammatory immune infiltrate which is unable to penetrate into the TIME due to stromal populations and secreted factors such as TGF- $\beta$ and VEGF. These latter two tumor environments are poorly responsive to checkpoint inhibition alone and new combination therapies are being investigated. Immunotherapeutic approaches include (A) blockade of inhibitory checkpoints, (B) stimulation of co-stimulatory checkpoints, (C) priming strategies to increase effective T-cell activation through stimulation of the innate immune system (e.g., radiation, oncolytic viral therapy 
and STING pathway agonists), (D) targeting immunomodulators (e.g., VEGF, TGF- $\beta$ ) and (E) introduction of primed or engineered $\mathrm{T}$ cells via adoptive cell therapy. CTL, cytotoxic $\mathrm{T}$ lymphocyte; DAMP, damage-associated molecular patterns; IDO, indole 2,3-dioxygenase; LAG-3, lymphocyte-activation gene 3; MDSC, myeloid-derived suppressor cell; MHC, major histocompatibility complex; PAMP, pathogen-associated molecular patterns; STING, stimulator of interferon genes; TAM, tumor-associated macrophage; TGF- $\beta$, transforming growth factor beta; TIGIT, T-cell immunoreceptor with Ig and ITIM domains; TIM-3, T-cell immunoglobulin and mucin-domaincontaining molecule 3; TLR, Toll-like receptor; VEGF, vascular endothelial growth factor. Adapted from "Tumor-Specific T cell Induction and Function", by BioRender.com (2020). Retrieved from https:/ / app.biorender.com/biorender-templates, accessed on 10 September 2021.

An effective anti-tumor immune response hinges upon appropriate priming of $\mathrm{T}$ cells capable of recognizing and killing tumor cells. Priming begins with the presentation of tumor antigens to naïve T cells via antigen-presenting cells (APCs) within the local draining lymph nodes. T-cell receptors (TCR) on CD4+ and CD8+ T cells recognize their specific peptide antigen when presented by MHC but require additional costimulatory signals in order to activate. The interaction between CD28 on T cells and its ligands CD80/CD86 on the APC constitutes the key co-stimulatory signal required for T-cell priming and represents the archetypal example of co-stimulation. Additional stimulation by inflammatory cytokines is also required for CD8+ T-cell activation and adoption of a Teffector phenotype. Activated T cells subsequently undergo clonal expansion, translocation to the TIME and may potentially engage in direct cytotoxicity against cancer cells displaying their cognate antigen. However, failure at the priming stage may lead to T-cell anergy or differentiation in a regulatory T-cell phenotype (Treg).

The functional tumor-killing potential of specific immune cell populations (e.g., T cells and NK cells) must be considered within the complex and dynamic cellular milieu of the TIME in which they must operate. The TIME structure is underpinned by a network of tumor cells interacting with multiple stromal cell populations as well as the extracellular matrix [2]. These elements may serve to modulate immune cell activity either through direct interaction, secretion of soluble factors or by preferentially attracting specific immune cell populations via chemotaxis. The immune cell populations present in the TIME are potentially varied and may contain both immune cell populations with tumor-killing potential as well as multiple immune cell populations that may alternatively promote or suppress immune cell activity [3]. The varied composition of the TIME has broadly been conceptualized into three categories — inflamed ("hot"), non-inflamed ("cold") and immune excluded (Figure 1).

An inflamed TIME is characterized by an active immune infiltrate with an abundance of cytotoxic $\mathrm{T}$ lymphocytes as well as other immune cell populations associated with antitumor immunity including dendritic cells (DC), NK cells and B cells. Tertiary lymphoid structures as well as plasma cells may also be present and support an anti-tumor immune response [4]. In contrast, a non-inflamed tumor is associated with an immunosuppressive TIME with minimal immune infiltrate or potentially tolerogenic immune cell populations such as Tregs, tumor-associated macrophages (TAMs) and myeloid-derived suppressor cells (MDSCs). Immune-excluded tumors often contain an active immune infiltrate which is displaced and unable to penetrate into the TIME likely secondary to immuno-modulatory stromal populations and secreted factors (e.g., TGF- $\beta$ ). Importantly, each of these immune categories should be considered a distinct entity produced by complex and varied immunologic mechanisms [5].

Careful study of the TIME has significant potential to reveal key mechanisms which underpin the interactions between tumor and immune cells resulting in the aforementioned immunologic states particularly in mNSCLC. It is precisely the nature of these pre-existing interactions that determines both the composition of the TIME as well as the potential success or failure of a given immunotherapeutic intervention. The presence of an active immune infiltrate with high-expression of co-inhibitory molecules such as PD-1/PD-L1 
associated with an inflamed TIME has been heavily associated with response to PD-1 inhibitors in mNSCLC [6,7]. In contrast, PD-1 inhibitors are thought to be less effective in mNSCLC patients with a non-inflamed TIME likely secondary to the absence of an immune infiltrate capable of recognizing and eliminating tumor cells in response to downregulation of co-inhibitory signaling through PD-1 [8]. The development of effective and rational combination immunotherapy capable of yielding improved clinical efficacy beyond existing PD-1/PD-L1 inhibitor therapy hinges upon understanding these immunologic states, the mechanisms that underpin them, and the appropriate targets that can unleash a potent anti-tumor immune response in these specific immunologic contexts.

\section{Co-Inhibitory and Co-Stimulatory Checkpoints}

\subsection{Co-Inhibitory Molecules}

Activated T cells express a number of co-inhibitory molecules on their surface that contribute to sustaining or suppressing a cell-mediated immune response. CTLA- 4 and PD1 are both inhibitory checkpoint molecules expressed on multiple immune cells including activated T cells. CTLA-4 binds CD80/86 with much higher affinity than CD28 and inhibits activation of T cells. Binding of PD-1 to its ligand PD-L1, which can be expressed on both tumor and immune cells, also results in inhibition of T-cell activation. Blockade of PD1/PD-L1 and CTLA-4 thus unleashes activated effector T cells to drive anti-tumor response within the TIME. There exist multiple additional co-inhibitory molecules (e.g., TIGIT, TIM-3, and LAG-3) which are potentially susceptible to therapeutic targeting. The development of novel combinations of drugs targeting co-inhibitory molecules is presently proceeding in earnest with the goal of improving upon the established efficacy of PD-1/PD-L1 inhibitor therapy in mNSCLC.

The use of PD-1/PD-L1 inhibitors transformed the mNSCLC treatment landscape and has demonstrated the ability to induce durable clinical benefit albeit in a subset of patients. The use of pembrolizumab (PD-1 inhibitor) in mNSCLC led to 5 year survival rates of $23 \%$ for treatment-naïve patients and $15 \%$ for those previously treated [1]. In patients with PD-L1 expression of $\geq 50 \%$, 5 year survival rates improved to $32 \%$, compared to $16 \%$ with standard platinum-doublet chemotherapy [9]. Atezolizumab is a PD-L1 inhibitor that also demonstrated improved survival compared to chemotherapy in patients with high PD-L1 expression, but not in those with lower expressions of PD-L1 [10]. Cemiplimab is another PD-1 inhibitor recently approved after demonstrating survival benefit, again in those patients with PD-L1 expression greater than 50\% [11]. PD-1 inhibitor nivolumab demonstrated benefit against chemotherapy in previously treated squamous and non-squamous patients [12], but interestingly failed to show significant benefit in first-line patients with PD-L1 expression $>5 \%$ [13]. Taken together, these findings provide a compelling rationale for the efficacy of PD-1 inhibitors in MNSCLC particularly with an inflamed TIME as well as the use of PD-1 inhibitors as a backbone for the development of novel immunotherapy combinations.

Ipilimumab is a CTLA-4 inhibitor which has been evaluated in combination with PD-1 inhibitors in mNSCLC. Ipilimumab-nivolumab, either alone or in combination with chemotherapy, has demonstrated survival benefit compared to chemotherapy alone [14,15]. The benefit of this combination immunotherapy appears consistent across PD-L1 status and may also be particularly beneficial in patients with treated brain metastases [16]. The recent KEYNOTE-598 trial evaluated ipilimumab-pembrolizumab in mNSCLC patients with PD-L1 $\geq 50 \%$ and failed to demonstrate improved survival compared to pembrolizumab alone [17]. It thus remains unclear as to which mNSCLC patients may derive improved clinical benefit from combination therapy with ipilimumab-nivolumab as opposed to PD-1 inhibitor therapy either alone or in combination with chemotherapy. There exists significant opportunity to define additional biomarkers in this context beyond PD-L1 expression alone to better identify patients that benefit from this combination. In particular, combination therapy with CTLA-4 may uniquely synergize with radiotherapy [18]. Ongoing trials using combinations of CTLA-4, PD-1 and other agents can be found in Table S1. 
T-cell immunoreceptor with Ig and ITIM domains (TIGIT) is a member of the CD28 family and potently inhibits innate and adaptive immunity through a number of mechanisms. TIGIT inhibits NK cell-mediated tumor killing and suppresses CD8+ T-cell activation as well as cytotoxicity $[19,20]$. TIGIT is co-expressed with PD-1 on exhausted T cells providing a compelling rationale that dual blockade of TIGIT and PD-1 can restore T-cell immunity [21]. A phase 1 study of vibostolimab (anti-TIGIT) in mNSCLC patients previously treated with ICI demonstrated tolerable toxicity and modest anti-tumor activity. ORR was $7 \%$ with vibostolimab alone and $5 \%$ when combined with pembrolizumab; however, the combination improved median DOR from 9 to 13 months [22]. Tiragolumab (anti-TIGIT) was recently evaluated in a randomized phase 2 trial in combination with atezolizumab in untreated $\mathrm{mNSCLC}$ with PD-L1 $\geq 1 \%$. Tiragolumab-atezolizumab provided a modest but statistically significant improvement in median PFS compared to atezolizumab alone, 5.6 months versus 3.9 months [23]. Interestingly, PFS benefit was most pronounced in those patients with high PD-L1 expression [24]. Phase 3 trials are underway in both front-line and later-line settings and these will hopefully highlight the patient subsets most likely to respond to this promising combination (Table S1).

Lymphocyte-activation gene 3 (LAG-3) is another co-inhibitory molecule expressed on T cells that binds MHC-II and inhibits activation of CD4+ cells. Preclinical studies have demonstrated co-expression of LAG-3 with PD-1 on exhausted T cells and that combined blockade results in synergistic anti-tumor immune activity [25,26]. Early-phase studies of eftilagimod alpha (IMP321), a soluble LAG-3 protein, demonstrated response in melanoma when combined with pembrolizumab [27] and there are encouraging initial results from a phase 2 study of the combination in mNSCLC with ORR reaching $47 \%$ and responses seen across PD-L1 expression levels [28]. Relatlimab is a LAG-3 antibody investigated in multiple solid tumors in combination with a range of other agents. Several other LAG-3 antibodies, fusion proteins and bi-specific molecules are also being evaluated in combination with other checkpoint inhibitors in mNSCLC (Table S1).

T-cell immunoglobulin and mucin-domain-containing molecule 3 (TIM-3) is expressed on tumor and immune cells and interaction with its ligands induces T-cell inhibition. Upregulation of TIM-3 on TILs is prognostic of poor outcome in multiple different cancers including NSCLC [29]. Preclinical work has suggested that blocking TIM-3 expression results in proliferation of $\mathrm{T}$ cells and cytokine production and demonstrates synergistic effect when combined with PD-1 blockade [30]. The phase 1 AMBER trial of TSR-022 (antiTIM3) in combination with a PD-1 inhibitor reported partial responses in 4 of 31 mNSCLC patients who had previously progressed on PD-1/PD-L1 inhibitors [31]. Additional earlyphase trials in solid tumors have suggested similar early signals of activity [32] (Table S1).

Indole 2,3-dioxygenase (IDO) is the rate-limiting enzyme involved in the conversion of tryptophan to kynurenine which promotes Treg and MDSC activity as well as suppresses T-effector cell activity. Multiple phase II studies of IDO1 inhibitors in combination with PD-1 inhibitors have suggested promising activity of this combination in multiple solid tumors [26]. A pivotal phase III trial of epacadostat (IDO1 inhibitor) and pembrolizumab in treatment-naïve metastatic melanoma has recently failed to demonstrate PFS benefit [33] This negative result has lessened enthusiasm for this drug class and many associated trials have been halted. The trial failure has largely been attributed to the unselected nature of the study population thus making the case for more in-depth biomarker analysis to select patients for such trials. Ongoing trials with epacadostat and other IDO inhibitors are listed in Table S1.

\subsection{Co-Stimulatory Molecules}

Co-stimulatory immune molecules promote T-cell activation and anti-tumor immunity, as well as shape the development of immune memory. As such, these molecules represent an attractive target to activate specific immune cell populations and promote anti-tumor immune activity. In particular, there exists significant opportunity to combine agonists 
of co-stimulatory molecules with PD-1 inhibitors in order to produce potent anti-tumor immune responses as well as potentially promote durable responses and immune memory. 4-1BB (CD137) is a member of the TNF receptor family which is expressed by several immune cells including activated T cells and NK cells. Binding of its ligand 4-1BBL promotes activation and proliferation of these cells leading to enhanced anti-tumor activity [34]. Additionally, 4-1BB activation is associated with the development of immune memory and represents an attractive target for the induction of durable immune responses. Two monoclonal antibodies that stimulate $4-1 \mathrm{BB}$ on $\mathrm{T}$ and NK cells have been evaluated in phase 1 trials with or without pembrolizumab. Urelumab is a non-ligand-blocking agonist which has been evaluated as monotherapy in a phase I clinical trial. This study demonstrated promising anti-tumor activity but a prohibitive level of immune-related hepatotoxicity potentially secondary to hyper-stimulation of 4-1BB secondary to antibody complex formation [35]. More recently, low-dose urelumab with PD-1 inhibitors has demonstrated reduced toxicity but disappointing activity amongst mNSCLC patients with only 1 of 34 patients achieving a response [36]. Utomilumab is a weaker agonist of 4-1BB found to exhibit a more favorable toxicity profile in early-phase studies although with limited activity as monotherapy [37]. A phase I study combining utomilumab with pembrolizumab demonstrated a response rate of 26\% [38] and trials with other PD-1/L1 inhibitors are ongoing (Table S1).

OX40 (CD134) is another member of the TNF receptor family that promotes activation, survival and proliferation of effector T cells [7,39]. Several OX40 agonist antibodies have been investigated in phase 1 trials of solid organ tumors, as both monotherapy or in combination with anti-PD-1 or anti-CTLA- 4 antibodies. Treatment has been reasonably tolerated but response rates have thus far been modest, between 7 and $13 \%$ in the combinations [40-42]. More work is needed to determine which patients will respond and which combinations will provide best response, and trials of other OX40 agents are ongoing (Table S1).

ICOS (CD278) is part of the CD28 co-receptor family and is expressed on activated $\mathrm{T}$ cells. It interacts with its ligand (ICOSL) to regulate effector and memory T-cell development, as well as the humoral immune response. It also has the capacity to trigger immunosuppressive activity through Tregs [19]. JTX-2011 (vopratelimab) was the first ICOS agonist antibody tested a phase 1 trial in advanced solid tumors as monotherapy or in combination with nivolumab. Treatment was tolerable but responses modest. A total of 3 of 34 combination patients had PR, and another 2 had stable disease [43]. A phase 2 study of vopratelimab in combination with ipilimumab in PD-1-treated mNSCLC and urothelial cancer was closed early due to failure to meet pre-specified interim criteria [44]. Another phase 2 trial of vopratelimab alone or in combination with a PD- 1 inhibitor in treatment-naïve mNSCLC patients is ongoing (NCT04549025). A novel ICOS agonist antibody GSK3359609 is also being evaluated as part of a platform trial of novel agents in PD-1 refractory mNSCLC (NCT03739710), and separately in combination with tremelimumab (NCT03693612).

Despite the promise of combination immunotherapy with co-stimulatory molecule agonists, only modest clinical benefit has been reported to date. This can largely be attributed to both significant complexities involved in manipulating co-stimulatory molecules as well as significant associated toxicity risks. The rationale for therapeutically targeting co-stimulatory molecules to induce immune cell activation and overcome an immunosuppressive TIME remains strong, and ongoing trials may yet demonstrate promising results (Table S1).

\section{Priming Strategies}

Immune therapy combinations described thus far have focused on improving T-cell anti-tumor activity through the blockade of inhibitory checkpoints or the activation of costimulatory molecules. However, the absence of an effective T-cell-mediated immune response may occur due to a lack of $\mathrm{T}$ cells which have been primed to respond to specific 
tumor antigens, producing an absent or deeply dysfunctional immune infiltrate classically associated with a non-inflamed TIME. Several strategies have been proposed to enhance T-cell priming in an effort to generate an effective T-cell-mediated anti-tumor immune response, which may then be augmented by the addition of established checkpoint inhibitors.

\subsection{Radiation}

Radiation therapy is known to promote immune-modulatory effects within the TIME through a range of mechanisms [7]. Key among these is the induction of immunogenic cell death whereby tumor cell killing via ionizing radiation elicits immune activation through the release of damage-associated molecular pattern molecules (DAMPs) that are recognized by the innate immune system [45]. Rapid recruitment of dendritic cells and macrophages leads to increased antigen presentation of tumor-associated antigens and migration of $\mathrm{T}$ cells to the tumor [46]. Synergistic effects have been seen with the combination of radiation and checkpoint inhibition in preclinical and clinical studies $[47,48]$.

The PACIFIC trial is perhaps the best-known radio-immunotherapy combination studied in NSCLC. Patients with unresectable stage III NSCLC who had not progressed following definitive chemoradiation were randomized to 12 months of PD-L1 inhibitor durvalumab or placebo. The 5 year outcomes were recently reported and the addition of durvalumab improved 60 month survival rates from 33\% to 43\% [49]. Subgroup analysis found that survival was higher in patients who commenced durvalumab within 14 days of radiation [50]. Recent small studies of pembrolizumab after SBRT in mNSCLC as well as following fractionated radiotherapy have also suggested enhanced clinical benefit from immunotherapy following radiotherapy [51,52].

Multiple trials of radiation in various combinations with PD-1 inhibitors, with or without chemotherapy, are proceeding across all stages of lung cancer (Table S1). There exists significant promise to utilize radiotherapy as a means of enhancing T-cell priming and immune activation in a fashion that may be particularly useful in immunologically cold or non-inflamed tumors particularly when utilized in combination with subsequent immune checkpoint inhibitors. A key outstanding question for the use of radiotherapy as a priming or combination immunotherapy strategy is the optimal timing and dosing for induction of an effective anti-tumor immune response as this may differ significantly from standard dosing utilized for ablative purposes.

\subsection{STING Agonists}

The stimulator of interferon genes (STING) pathway is an immune sensing pathway triggered by the presence of cytosolic DNA [53]. The STING pathway has been implicated in the danger response associated with radiation-induced immunogenic cell death as well as viral infections. DNA in the cytosol is detected by cyclic GMP-AMP synthase (cGAS) which activates STING, a protein located in the endoplasmic reticulum. Activated STING initiates a signaling cascade that results in transcription and production of inflammatory cytokines, promoting local DC maturation and activation, enhanced trafficking of immune cells, and CTL-mediating tumor killing (Figure 1) [54,55].

Based on preclinical observations of this pathway in action against implanted tumors, STING agonists have been explored as an alternative mechanism to create a more antitumorigenic TIME, that may then respond better to checkpoint inhibition. MIW815 (ADUS100) was the first STING agonist to be tested clinically in a phase 1 trial of patients with advanced solid tumors or lymphoma. Patients received intratumoral injections of the agonist, in combination with intravenous anti-PD-1 spartalizumab [56]. It was well tolerated and demonstrated anti-tumor activity in PD-1-naïve triple-negative breast cancer and PD-1 refractory melanoma. Unfortunately, the study was discontinued by the sponsor due to limited clinical efficacy [57]. Another intratumoral STING agonist MK-1454 had minimal response when used as monotherapy in patients with advanced solid tumors, but $24 \%$ in combination with pembrolizumab [58]. Several other STING agonists or modulators of the STING pathway are being investigated (Table S1). Some of these can be administered 
more conveniently intravenously or intramuscularly, and an orally available STING agonist has demonstrated anti-tumor activity in preclinical models [59].

\subsection{TLR Agonists}

Another potential mechanism to activate the innate immune system is via Toll-like receptors, protein receptors on innate immune cells that recognize pathogen-associated and damage-associated molecular patterns (PAMPs and DAMPs). The role of TLRs in cancer, however, is complex and the specific TLR activated depends on the nature of the threat and the localization of the TLR. TLRs 1, 2, 5, 6 are located on the cell surface and predominantly respond to bacterial proteins, while TLR 3, 7, 8 and 9 are intracellular and are activated by foreign DNA taken up by the cell. Activated TLRs can promote production of pro-inflammatory cytokines, activation of APCs and induction of T-effector cells, but some can also promote angiogenesis and tumor invasion.

A range of TLR agonists have been developed but the complexity of the TLR role has been an obstacle. The most evidence to date has focused on TLR9 agonists, which are designed as analogues of the PAMP recognized by TLR9. These are largely administered via intratumoral or subcutaneous routes to enhance anti-tumor immune activity as well as limit systemic toxicity. A phase 1 study of TLR agonist tilsotolimod demonstrated moderate responses in heavily pretreated solid tumors and was reasonably tolerated [60]. Post-treatment biopsies revealed increased expression of multiple immune checkpoints, which suggests significant potential for combining their use with checkpoint inhibitors. A phase $1 / 2$ study investigated the combination of tilsotolimod with ipilimumab in post-PD-1 treated melanoma. The disease control rate was 71\%, with durable disease control [61]. However, the subsequent phase 3 trial did not meet its primary endpoint [62]. More trials are underway with other agonists of TLR9 and other TLRs in combination with checkpoint inhibitors (Table S1).

\subsection{Oncolytic Viruses}

Oncolytic virus (OV) therapy is another strategy aimed at promoting immune activation via targeted immunogenic cell death [63]. Oncolytic viruses are modified to preferentially infect tumor cells and their introduction into the TIME causes tumor cell lysis, release of DAMPs and PAMPs, activating innate immune sensors and recruitment of immune cells to drive an anti-tumor immune response $[64,65]$.

The best studied OV is T-VEC (talimogene laherparepvec), a modified herpes simplex type 1 virus that contains a gene insertion encoding GM-CSF which further promotes recruitment and activation of APCs. It demonstrated significant responses in a phase 3 study when injected intratumorally in melanoma patients, leading to FDA approval $[66,67]$. The combination of OVs with checkpoint inhibitors is thought to be synergistic by creating and then sustaining an immunogenic, anti-tumor TIME. Early-phase studies combining T-VEC with ipilimumab or pembrolizumab in melanoma showed promising results $[68,69]$. A phase III study with T-VEC and pembrolizumab however was halted over futility at interim analysis. There have been limited studies to date of OVs in lung cancer. A phase II trial of TG4010, a modified vaccinia virus, in combination with nivolumab in metastatic NSCLC failed to meet its primary endpoint and further development has ceased [70]. CAVATAK, a modified coxsackievirus A21, in combination with pembrolizumab, demonstrated encouraging efficacy with response rates of $30 \%$ and was well-tolerated in a phase $1 \mathrm{~b}$ study of patients with advanced NSCLC [71].

\subsection{Cytokines}

Inflammatory cytokines play a key role in T-cell priming as well as promoting and regulating cell-mediated immune responses. High-dose IL-2 monotherapy has been previously demonstrated to be able to induce durable clinical responses in melanoma as well as RCC but has been associated with significant toxicity which has limited its current use. The success of PD-1/PD-L1 inhibitors has generated renewed interest in the use of systemic 
inflammatory cytokines to augment the activity of immune checkpoint inhibitors as well as certain adoptive cell therapy strategies [72,73]. NKTR-214 (pegylated IL-2) combined with a PD-1 inhibitor is currently being evaluated in mNSCLC with early data suggesting potential activity of this combination as well as its potential to impact the composition of the TIME [74]. Additional inflammatory cytokine analogues such as IL-15 super-agonists are also currently in development $[75,76]$.

\section{VEGF, Targeted Therapy and Other Immunomodulators}

\subsection{VEGF}

Multiple cytokines within the TIME play important roles in making it more immunosuppressive or immunostimulatory, and vascular endothelial growth factor (VEGF) and transforming growth factor beta (TGF- $\beta$ ) have both been studied as therapeutic targets. VEGF is predominantly involved in regulating angiogenesis, which is required for tumor growth; however, increasing evidence suggests that it also contributes to an immunosuppressive TIME. It acts via endothelial factors to physically prevent T-cell infiltration into the tumor, while suppressing dendritic cell maturation and promoting inhibitory Tregs and MDSCs [61-63]. TGF- $\beta$ also mediates an immunosuppressive TIME through induction of Tregs, inhibition of Teff and promotion of angiogenesis and epithelial-mesenchymal transition, which are integral for tumor progression [77].

Anti-VEGF/VEGFR agents bevacizumab, ramucirumab and nintedanib have all demonstrated improved outcomes when combined with chemotherapy in treatment of lung cancer [78-80]. There is significant potential for greater response by using agents that inhibit VEGF-mediated immunosuppression to create a more immunogenic environment that allows for enhanced anti-tumor activity of checkpoint inhibitors [81]. The combination of chemoimmunotherapy and bevacizumab in IMpower150 demonstrated a survival benefit compared to chemotherapy and bevacizumab without atezolizumab, which supports the premise of a synergistic relationship between checkpoint blockade and bevacizumab [82].

Improved survival with the combination in IMpower150 was seen across all clinical subgroups, including patients with liver metastases and patients with EGFR and ALK driver mutations [50]. Liver metastases in NSCLC are a poor prognostic indicator and studies have previously shown limited benefit for this population with checkpoint-inhibitor monotherapy [83]. Patients with EGFR and ALK alterations who have failed first-line targeted therapy also do poorly with subsequent lines of therapy and trials have shown that outcomes with single-agent checkpoint inhibitors are not better than with standard chemotherapy [84]. The survival benefit with the IO-bevacizumab combination for these patient populations is encouraging and the precise mechanisms by which this is achieved are being explored. EGFR mutations and hepatocellular cancers are known to express high amounts of VEGF that make them more susceptible to VEGF inhibition, switching the TIME to a more immune-tolerant one susceptible to checkpoint blockade. More work is also being done investigating VEGFR and multi-targeted TKIs in combination with ICIs. Early-phase trials to date [85-88] have shown encouraging results but larger, randomized trials are awaited.

\section{2. $T G F-\beta$}

Trials with agents targeting TGF- $\beta$ have been more challenging due to the complexities of TGF- $\beta$ signaling pathways. One promising agent is bintrafusp alfa, a bifunctional fusion protein with a TGF- $\beta$ "trap" fused to a PD-L1 monoclonal antibody. Concurrent inhibition of these two inhibitory pathways in a phase 1 study of patients with advanced NSCLC after progression on chemotherapy demonstrated favorable clinical activity, particularly in PD-L1 high tumors [89]. However, a phase 3 study randomizing PD-L1-positive mNSCLC patients to bintrafusp alpha or pembrolizumab failed to meet its primary endpoint [90]. Phase 2 studies in combination with chemotherapy and trials of other TGF- $\beta$ targeting agents are ongoing (Table S1). 


\subsection{Targeted Therapy}

The presence of specific driver mutations and co-mutations has been previously demonstrated to exert significant impact on the composition of the TIME in mNSCLC. This impact is perhaps most pronounced amongst KRAS mutant tumors where the presence of p53, LKB1 and KEAP1 co-mutations may produce drastically different TIME and likelihood of response to ICI [91]. This has led to significant interest in combining targeted therapies directed against targetable driver mutations with immunotherapy strategies. Early trials evaluating the combination of EGFR and ALK TKIs with PD1 inhibitors were largely curtailed by significant synergistic toxicity. The recent development of direct KRAS G12C inhibitors has renewed interest in the utility of combining targeted therapy with PD1 inhibitors particularly in classically PD-1 refractory KRAS-LKB1 and KRAS-KEAP1 Comutated mNSCLC $[92,93]$. Multiple clinical trials are presently underway with combination arms evaluating G12C inhibitor and PD1 inhibitor strategies (Table S1).

\section{Adoptive Cell Therapy}

The strategies discussed so far have focused primarily on modifying the TIME through the stimulation of pre-existing native immune cells. An alternative strategy currently under investigation is adoptive cellular therapy (ACT), in which ex vivo expanded or engineered $\mathrm{T}$ cells are manufactured and directly infused into patients with the goal of increasing tumor-specific effector cells capable of driving a strong anti-tumor immune response [7].

Tumor-infiltrating lymphocyte (TIL) therapy involves the isolation of lymphocytes from an autologous tumor sample, ex vivo stimulation and expansion followed by infusion back into the patient [94]. Pre-infusion lymphodepletion removes competing and immunosuppressive cells, and post-infusion high-dose IL-2 promotes TIL activation and proliferation [95]. Early data suggest the potential for durable responses in melanoma patients [96]. A recently reported phase 1 study of TILs in combination with nivolumab in 20 patients with advanced anti-PD-1 resistant NSCLC demonstrated durable anti-tumor responses. Six out of 13 evaluable patients had confirmed radiographic response, and 2 of these had a complete response, which was ongoing at 1.5 years [97].

Engineered TCRs are an alternative approach to re-introduce T cells with receptors designed to target specific tumor neoantigen/MHC combinations. Engineered TCRs are inherently restricted to responding to antigens presented by specific HLA molecules which can both be difficult for patient selection as well as the potential for tumors to downregulate HLA expression as a mechanism of resistance [94]. Limitations secondary to HLA restriction can be potentially obviated through the use of chimeric antigen receptor T cells (CAR-T), which are synthetic hybrid receptors combining an extracellular antibody-derived receptor specific for tumor antigen with an intracellular activating domain [98]. Newer generations of CARs have been engineered to include costimulatory domains such as CD28 and 4$1 \mathrm{BB}$ to enhance and maintain T-cell response, and so-called "armored" CAR-T cells have been developed to secrete pro-inflammatory cytokines [94]. CD19 CAR-T cells have been hugely successful in treating relapsed / refractory leukemias and lymphomas $[99,100]$. The combination of ACT strategies with other immunotherapeutic strategies (e.g., ICI, cytokines) has significant potential to augment the activity and durability of adoptively transferred immune cell populations. Trials investigating the combination are ongoing in both hematological and solid tumors. Additional strategies utilizing bi-specific T-cell engagers (BiTEs) as well as novel tumor neo-antigen vaccination approaches are also in development (Table S1).

\section{Conclusions}

The success of PD-1 inhibitors has demonstrated the potentially transformational power of immunotherapy in mNSCLC. For the first time, we have seen that functional cures are now possible in mNSCLC albeit among a minority of patients. The challenge now facing us is the development of the next generation of rational immunotherapy combinations capable of ensuring durable long-term response and functional cure for a broader 
population. Careful consideration of the complex tumor-immune interactions that sculpt the TIME is key to understanding the factors and mechanisms that ultimately determine the success or failure of a given combination immunotherapy strategy. Importantly, a clear understanding of these mechanisms is key to developing rational biomarker-driven clinical trials of novel combination immunotherapeutic strategies. Multiple such promising combination strategies are currently in development with highly disparate targets and underlying mechanisms of action including co-inhibitory molecules, co-stimulatory molecules and a litany of immuno-modulatory and adoptive cell therapy strategies. In this context, there exists significant risk that a biomarker-agnostic "one-size-fits-all" approach to drug development with limited consideration for individual TIME characteristics will risk further high-profile failures of novel immunotherapy combinations. Furthermore, this approach risks inappropriately discarding promising combinations that may be active in defined subsets of patients but for whom any signal of activity is lost in a broad, non-biomarker defined study population. Careful consideration of the immunologic characteristics of $\mathrm{mN}$ SCLC patients will be essential to ensuring that the right combination immunotherapy is studied in a biomarker-driven trial focused on patients with a susceptible TIME. Significant potential exists for the myriad aforementioned combination immunotherapy strategies to transform the treatment of mNSCLC. However, the complexity of our approach to the development of the next-generation of immunotherapies must meet the complex challenges inherent in the immunobiology of NSCLC.

Supplementary Materials: The following supporting information can be downloaded at: https: / / www.mdpi.com/article/10.3390/curroncol29010004/s1, Table S1. Ongoing or recently completed trials of immune checkpoint inhibitors (IO) in combination with novel targets for advanced nonsmall-cell lung cancer (NSCLC) [101-146].

Author Contributions: L.C., A.S. contributed to the conceptualization and writing of the manuscript. All authors have read and agreed to the published version of the manuscript.

Funding: This research received no external funding.

Conflicts of Interest: (A.S.) Consulting \& Honoraria: Amgen, AstraZeneca, Merck, Genentech-Roche, Bayer, BMS, Pfizer, Tesaro, and KisoJi. Contracted Research: Genentech-Roche and AstraZeneca.

\section{References}

1. Garon, E.B.; Hellmann, M.D.; Rizvi, N.A.; Carcereny, E.; Leighl, N.B.; Ahn, M.-J.; Eder, J.P.; Balmanoukian, A.S.; Aggarwal, C.; Horn, L.; et al. Five-Year Overall Survival for Patients with Advanced Non-Small-Cell Lung Cancer Treated With Pembrolizumab: Results From the Phase I KEYNOTE-001 Study. J. Clin. Oncol. 2019, 37, 2518-2527. [CrossRef] [PubMed]

2. Pitt, J.M.; Marabelle, A.; Eggermont, A.; Soria, J.C.; Kroemer, G.; Zitvogel, L. Targeting the tumor microenvironment: Removing obstruction to anticancer immune responses and immunotherapy. Ann. Oncol. 2016, 27, 1482-1492. [CrossRef] [PubMed]

3. Camus, M.; Tosolini, M.; Mlecnik, B.; Pages, F.; Kirilovsky, A.; Berger, A.; Costes, A.; Bindea, G.; Charoentong, P.; Bruneval, P.; et al. Coordination of intratumoral immune reaction and human colorectal cancer recurrence. Cancer Res. 2009, 69, 2685-2693. [CrossRef] [PubMed]

4. Taube, J.M.; Galon, J.; Sholl, L.M.; Rodig, S.J.; Cottrell, T.R.; Giraldo, N.A.; Baras, A.S.; Patel, S.S.; Anders, R.A.; Rimm, D.L.; et al Implications of the tumor immune microenvironment for staging and therapeutics. Mod. Pathol. 2018, 31, 214-234. [CrossRef] [PubMed]

5. Duan, Q.; Zhang, H.; Zheng, J.; Zhang, L. Turning Cold into Hot: Firing up the Tumor Microenvironment. Trends Cancer 2020, 6, 605-618. [CrossRef] [PubMed]

6. $\quad$ Binnewies, M.; Roberts, E.W.; Kersten, K.; Chan, V.; Fearon, D.F.; Merad, M.; Coussens, L.M.; Gabrilovich, D.I.; Ostrand-Rosenberg, S.; Hedrick, C.C.; et al. Understanding the tumor immune microenvironment (TIME) for effective therapy. Nat. Med. 2018, 24, 541-550. [CrossRef]

7. Murciano-Goroff, Y.R.; Warner, A.B.; Wolchok, J.D. The future of cancer immunotherapy: Microenvironment-targeting combinations. Cell Res. 2020, 30, 507-519. [CrossRef] [PubMed]

8. Galon, J.; Bruni, D. Approaches to treat immune hot, altered and cold tumours with combination immunotherapies. Nat. Rev. Drug Discov. 2019, 18, 197-218. [CrossRef]

9. Reck, M.; Rodríguez-Abreu, D.; Robinson, A.G.; Hui, R.; Csőszi, T.; Fülöp, A.; Gottfried, M.; Peled, N.; Tafreshi, A.; Cuffe, S.; et al. Five-Year Outcomes With Pembrolizumab Versus Chemotherapy for Metastatic Non-Small-Cell Lung Cancer With PD-L1 Tumor Proportion Score $\geq 50 \%$. J. Clin. Oncol. 2021, 39, 2339-2349. [CrossRef] 
10. Herbst, R.S.; Giaccone, G.; de Marinis, F.; Reinmuth, N.; Vergnenegre, A.; Barrios, C.H.; Morise, M.; Felip, E.; Andric, Z.; Geater, S.; et al. Atezolizumab for First-Line Treatment of PD-L1-Selected Patients with NSCLC. N. Engl. J. Med. 2020, 383, 1328-1339. [CrossRef] [PubMed]

11. Sezer, A.; Kilickap, S.; Gümüş, M.; Bondarenko, I.; Özgüroğlu, M.; Gogishvili, M.; Turk, H.M.; Cicin, I.; Bentsion, D.; Gladkov, O.; et al. Cemiplimab monotherapy for first-line treatment of advanced non-small-cell lung cancer with PD-L1 of at least $50 \%$ : A multicentre, open-label, global, phase 3, randomised, controlled trial. Lancet 2021, 397, 592-604. [CrossRef]

12. Borghaei, H.; Gettinger, S.; Vokes, E.E.; Chow, L.Q.M.; Burgio, M.A.; Carpeno, J.d.C.; Pluzanski, A.; Arrieta, O.; Frontera, O.A.; Chiari, R.; et al. Five-Year Outcomes From the Randomized, Phase III Trials CheckMate 017 and 057: Nivolumab Versus Docetaxel in Previously Treated Non-Small-Cell Lung Cancer. J. Clin. Oncol. 2021, 39, 723-733. [CrossRef] [PubMed]

13. Carbone, D.P.; Reck, M.; Paz-Ares, L.; Creelan, B.; Horn, L.; Steins, M.; Felip, E.; van den Heuvel, M.M.; Ciuleanu, T.-E.; Badin, F.; et al. First-Line Nivolumab in Stage IV or Recurrent Non-Small-Cell Lung Cancer. N. Engl. J. Med. 2017, 376, 2415-2426. [CrossRef] [PubMed]

14. Paz-Ares, L.; Ciuleanu, T.-E.; Cobo, M.; Schenker, M.; Zurawski, B.; Menezes, J.; Richardet, E.; Bennouna, J.; Felip, E.; Juan-Vidal, O.; et al. First-line nivolumab plus ipilimumab combined with two cycles of chemotherapy in patients with non-small-cell lung cancer (CheckMate 9LA): An international, randomised, open-label, phase 3 trial. Lancet Oncol. 2021, 22, 198-211. [CrossRef]

15. Hellmann, M.D.; Paz-Ares, L.; Bernabe Caro, R.; Zurawski, B.; Kim, S.-W.; Carcereny Costa, E.; Park, K.; Alexandru, A.; Lupinacci, L.; de la Mora Jimenez, E.; et al. Nivolumab plus Ipilimumab in Advanced Non-Small-Cell Lung Cancer. N. Engl. J. Med. 2019, 381, 2020-2031. [CrossRef] [PubMed]

16. Borghaei, H.; Pluzanski, A.; Caro, R.B.; Provencio, M.; Burgers, S.; Carcereny, E.; Park, K.; Alexandru, A.; Lupinacci, L.; Sangha, R.; et al. Abstract CT221: Nivolumab (NIVO) + ipilimumab (IPI) as first-line (1L) treatment for patients with advanced non-small cell lung cancer (NSCLC) with brain metastases: Results from CheckMate 227. Cancer Res. 2020, 80, CT221. [CrossRef]

17. Boyer, M.; Şendur, M.A.N.; Rodríguez-Abreu, D.; Park, K.; Lee, D.H.; Çiçin, I.; Yumuk, P.F.; Orlandi, F.J.; Leal, T.A.; Molinier, O.; et al. Pembrolizumab Plus Ipilimumab or Placebo for Metastatic Non-Small-Cell Lung Cancer With PD-L1 Tumor Proportion Score $\geq 50 \%$ : Randomized, Double-Blind Phase III KEYNOTE-598 Study. J. Clin. Oncol. 2021, 39, 2327-2338. [CrossRef]

18. Harding, S.M.; Benci, J.L.; Irianto, J.; Discher, D.E.; Minn, A.J.; Greenberg, R.A. Mitotic progression following DNA damage enables pattern recognition within micronuclei. Nature 2017, 548, 466-470. [CrossRef] [PubMed]

19. Lee, J.B.; Ha, S.-J.; Kim, H.R. Clinical Insights Into Novel Immune Checkpoint Inhibitors. Front. Pharm. 2021, 12, 681320. [CrossRef] [PubMed]

20. Solomon, B.L.; Garrido-Laguna, I. TIGIT: A novel immunotherapy target moving from bench to bedside. Cancer Immunol. Immunother. 2018, 67, 1659-1667. [CrossRef] [PubMed]

21. Johnston, R.J.; Comps-Agrar, L.; Hackney, J.; Yu, X.; Huseni, M.; Yang, Y.; Park, S.; Javinal, V.; Chiu, H.; Irving, B.; et al. The immunoreceptor TIGIT regulates antitumor and antiviral CD8(+) T cell effector function. Cancer Cell 2014, 26, 923-937. [CrossRef] [PubMed]

22. Ahn, M.J.; Niu, J.; Kim, D.W.; Rasco, D.; Mileham, K.F.; Chung, H.C.; Vaishampayan, U.N.; Maurice-Dror, C.; Lo Russo, P.; Golan, T.; et al. 1400P Vibostolimab, an anti-TIGIT antibody, as monotherapy and in combination with pembrolizumab in anti-PD-1/PD-L1-refractory NSCLC. Ann. Oncol. 2020, 31, S887. [CrossRef]

23. Rodriguez-Abreu, D.; Johnson, M.L.; Hussein, M.A.; Cobo, M.; Patel, A.J.; Secen, N.M.; Lee, K.H.; Massuti, B.; Hiret, S.; Yang, J.C.-H.; et al. Primary analysis of a randomized, double-blind, phase II study of the anti-TIGIT antibody tiragolumab (tira) plus atezolizumab (atezo) versus placebo plus atezo as first-line (1L) treatment in patients with PD-L1-selected NSCLC (CITYSCAPE). J. Clin. Oncol. 2020, 38, 9503. [CrossRef]

24. Patil, N.; Cho, B.C.; Johnson, M.; Caro, R.B.; Spira, A.; Chiu, C.; Molden, N.; Pham, T.; Yang, X.; Choi, Y.; et al. P77.02 Efficacy of Tiragolumab + Atezolizumab in PD-L1 IHC and TIGIT Subgroups in the Phase II CITYSCAPE Study in First-Line NSCLC. J. Thorac. Oncol. 2021, 16, S635-S636. [CrossRef]

25. Woo, S.R.; Turnis, M.E.; Goldberg, M.V.; Bankoti, J.; Selby, M.; Nirschl, C.J.; Bettini, M.L.; Gravano, D.M.; Vogel, P.; Liu, C.L.; et al Immune inhibitory molecules LAG-3 and PD-1 synergistically regulate T-cell function to promote tumoral immune escape. Cancer Res. 2012, 72, 917-927. [CrossRef] [PubMed]

26. Yap, T.A.; Parkes, E.E.; Peng, W.; Moyers, J.T.; Curran, M.A.; Tawbi, H.A. Development of Immunotherapy Combination Strategies in Cancer. Cancer Discov. 2021, 11, 1368-1397. [CrossRef] [PubMed]

27. Atkinson, V.; Khattak, A.; Haydon, A.; Eastgate, M.; Roy, A.; Prithviraj, P.; Mueller, C.; Brignone, C.; Triebel, F. Eftilagimod alpha, a soluble lymphocyte activation gene-3 (LAG-3) protein plus pembrolizumab in patients with metastatic melanoma. J. Immunother. Cancer 2020, 8, e001681. [CrossRef] [PubMed]

28. Felip, E.; Doger, B.; Majem, M.; Carcereny, E.; Krebs, M.; Peguero, J.A.; Roxburgh, P.; Forster, M.; Bajaj, P.; Clay, T.D.; et al Initial results from a phase II study (TACTI-002) in metastatic non-small cell lung or head and neck carcinoma patients receiving eftilagimod alpha (soluble LAG-3 protein) and pembrolizumab. J. Clin. Oncol. 2020, 38, 3100. [CrossRef]

29. Gao, X.; Zhu, Y.; Li, G.; Huang, H.; Zhang, G.; Wang, F.; Sun, J.; Yang, Q.; Zhang, X.; Lu, B. TIM-3 expression characterizes regulatory $\mathrm{T}$ cells in tumor tissues and is associated with lung cancer progression. PLoS ONE 2012, 7, e30676. [CrossRef]

30. Koyama, S.; Akbay, E.A.; Li, Y.Y.; Herter-Sprie, G.S.; Buczkowski, K.A.; Richards, W.G.; Gandhi, L.; Redig, A.J.; Rodig, S.J.; Asahina, H.; et al. Adaptive resistance to therapeutic PD-1 blockade is associated with upregulation of alternative immune checkpoints. Nat. Commun. 2016, 7, 10501. [CrossRef] [PubMed] 
31. Davar, D.; Boasberg, P.; Eroglu, Z. A phase 1 study of TSR-022, an anti-TIM-3 monoclonal antibody, in combination with TSR-042 (anti-PD-1) in patients with colorectal cancer and post-PD-1 NSCLC and melanoma. J. Immunother. Cancer 2018, 6, 114.

32. Harding, J.J.; Moreno, V.; Bang, Y.J.; Hong, M.H.; Patnaik, A.; Trigo, J.; Szpurka, A.M.; Yamamoto, N.; Doi, T.; Fu, S.; et al Blocking TIM-3 in Treatment-refractory Advanced Solid Tumors: A Phase Ia/b Study of LY3321367 with or without an Anti-PD-L1 Antibody. Clin. Cancer Res. 2021, 27, 2168-2178. [CrossRef] [PubMed]

33. Long, G.V.; Dummer, R.; Hamid, O.; Gajewski, T.F.; Caglevic, C.; Dalle, S.; Arance, A.; Carlino, M.S.; Grob, J.-J.; Kim, T.M.; et al. Epacadostat plus pembrolizumab versus placebo plus pembrolizumab in patients with unresectable or metastatic melanoma (ECHO-301/KEYNOTE-252): A phase 3, randomised, double-blind study. Lancet Oncol. 2019, 20, 1083-1097. [CrossRef]

34. Qi, X.; Li, F.; Wu, Y.; Cheng, C.; Han, P.; Wang, J.; Yang, X. Optimization of 4-1BB antibody for cancer immunotherapy by balancing agonistic strength with Fc $\gamma$ R affinity. Nat. Commun. 2019, 10, 2141. [CrossRef] [PubMed]

35. Sznol, M.; Hodi, F.S.; Margolin, K.; McDermott, D.F.; Ernstoff, M.S.; Kirkwood, J.M.; Wojtaszek, C.; Feltquate, D.; Logan, T. Phase I study of BMS-663513, a fully human anti-CD137 agonist monoclonal antibody, in patients (pts) with advanced cancer (CA). J. Clin. Oncol. 2008, 26, 3007. [CrossRef]

36. Lundqvist, A.; van Hoef, V.; Zhang, X.; Wennerberg, E.; Lorent, J.; Witt, K.; Sanz, L.M.; Liang, S.; Murray, S.; Larsson, O.; et al. 31st Annual Meeting and Associated Programs of the Society for Immunotherapy of Cancer (SITC 2016): Part one. J. ImmunoTher. Cancer 2016, 4, 82. [CrossRef]

37. Segal, N.H.; He, A.R.; Doi, T.; Levy, R.; Bhatia, S.; Pishvaian, M.J.; Cesari, R.; Chen, Y.; Davis, C.B.; Huang, B.; et al. Phase I Study of Single-Agent Utomilumab (PF-05082566), a 4-1BB/CD137 Agonist, in Patients with Advanced Cancer. Clin. Cancer Res. 2018, 24, 1816-1823. [CrossRef]

38. Tolcher, A.W.; Sznol, M.; Hu-Lieskovan, S.; Papadopoulos, K.P.; Patnaik, A.; Rasco, D.W.; Di Gravio, D.; Huang, B.; Gambhire, D.; Chen, Y.; et al. Phase Ib Study of Utomilumab (PF-05082566), a 4-1BB/CD137 Agonist, in Combination with Pembrolizumab (MK-3475) in Patients with Advanced Solid Tumors. Clin. Cancer Res. 2017, 23, 5349-5357. [CrossRef]

39. Aspeslagh, S.; Postel-Vinay, S.; Rusakiewicz, S.; Soria, J.-C.; Zitvogel, L.; Marabelle, A. Rationale for anti-OX40 cancer immunotherapy. Eur. J. Cancer 2016, 52, 50-66. [CrossRef]

40. Goldman, J.W.; Piha-Paul, S.A.; Curti, B.D.; Pedersen, K.; Bauer, T.M.; Groenland, S.L.; Carvajal, R.D.; Chhaya, V.; Hammond, S.A.; Streicher, K.; et al. Safety and tolerability of MEDI0562 in combination with durvalumab or tremelimumab in patients with advanced solid tumors. J. Clin. Oncol. 2020, 38, 3003. [CrossRef]

41. Postel-Vinay, S.; Lam, V.K.; Ros, W.; Bauer, T.M.; Hansen, A.R.; Cho, D.C.; Hodi, F.S.; Schellens, J.H.M.; Litton, J.K.; Aspeslagh, S.; et al. Abstract CT150: A first-in-human phase I study of the OX40 agonist GSK3174998 (GSK998) +/- pembrolizumab in patients (Pts) with selected advanced solid tumors (ENGAGE-1). Cancer Res. 2020, 80, CT150. [CrossRef]

42. Gutierrez, M.; Moreno, V.; Heinhuis, K.M.; Olszanski, A.J.; Spreafico, A.; Ong, M.; Chu, Q.; Carvajal, R.D.; Trigo, J.; Ochoa de Olza, M.; et al. OX40 Agonist BMS-986178 Alone or in Combination With Nivolumab and/or Ipilimumab in Patients with Advanced Solid Tumors. Clin. Cancer Res. 2021, 27, 460-472. [CrossRef] [PubMed]

43. Yap, T.A.; Burris, H.A.; Kummar, S.; Falchook, G.S.; Pachynski, R.K.; LoRusso, P.; Tykodi, S.S.; Gibney, G.T.; Gainor, J.F.; Rahma, O.E.; et al. ICONIC: Biologic and clinical activity of first in class ICOS agonist antibody JTX-2011 + / - nivolumab (nivo) in patients (pts) with advanced cancers. J. Clin. Oncol. 2018, 36, 3000. [CrossRef]

44. Jounce Therapeutics Announces Update on Vopratelimab Program. Available online: https://ir.jouncetx.com/news-releases/ news-release-details/jounce-therapeutics-announces-update-vopratelimab-program (accessed on 8 September 2021)

45. Jiang, W.; Chan, C.K.; Weissman, I.L.; Kim, B.Y.S.; Hahn, S.M. Immune Priming of the Tumor Microenvironment by Radiation. Trends Cancer 2016, 2, 638-645. [CrossRef] [PubMed]

46. Smyth, M.J.; Ngiow, S.F.; Ribas, A.; Teng, M.W. Combination cancer immunotherapies tailored to the tumour microenvironment. Nat. Rev. Clin. Oncol. 2016, 13, 143-158. [CrossRef] [PubMed]

47. Heinzerling, J.H.; Mileham, K.F.; Simone, C.B. The utilization of immunotherapy with radiation therapy in lung cancer: A narrative review. Transl. Cancer Res. 2021, 10, 2596-2608. [CrossRef]

48. Ko, E.C.; Raben, D.; Formenti, S.C. The Integration of Radiotherapy with Immunotherapy for the Treatment of Non-Small Cell Lung Cancer. Clin. Cancer Res. 2018, 24, 5792-5806. [CrossRef]

49. Spigel, D.R.; Faivre-Finn, C.; Gray, J.E.; Vicente, D.; Planchard, D.; Paz-Ares, L.G.; Vansteenkiste, J.F.; Garassino, M.C.; Hui, R.; Quantin, X.; et al. Five-year survival outcomes with durvalumab after chemoradiotherapy in unresectable stage III NSCLC: An update from the PACIFIC trial. J. Clin. Oncol. 2021, 39, 8511. [CrossRef]

50. Gray, J.E.; Villegas, A.; Daniel, D.; Vicente, D.; Murakami, S.; Hui, R.; Kurata, T.; Chiappori, A.; Lee, K.H.; Cho, B.C.; et al. Three-Year Overall Survival with Durvalumab after Chemoradiotherapy in Stage III NSCLC-Update from PACIFIC. J. Thorac. Oncol. 2020, 15, 288-293. [CrossRef] [PubMed]

51. Theelen, W.; Peulen, H.M.U.; Lalezari, F.; van der Noort, V.; de Vries, J.F.; Aerts, J.; Dumoulin, D.W.; Bahce, I.; Niemeijer, A.N.; de Langen, A.J.; et al. Effect of Pembrolizumab After Stereotactic Body Radiotherapy vs Pembrolizumab Alone on Tumor Response in Patients With Advanced Non-Small Cell Lung Cancer: Results of the PEMBRO-RT Phase 2 Randomized Clinical Trial. JAMA Oncol. 2019, 5, 1276-1282. [CrossRef]

52. Welsh, J.; Menon, H.; Chen, D.; Verma, V.; Tang, C.; Altan, M.; Hess, K.; de Groot, P.; Nguyen, Q.N.; Varghese, R.; et al. Pembrolizumab with or without radiation therapy for metastatic non-small cell lung cancer: A randomized phase I/II trial. J. Immunother. Cancer 2020, 8, e001001. [CrossRef] [PubMed] 
53. Marin-Acevedo, J.A.; Kimbrough, E.O.; Manochakian, R.; Zhao, Y.; Lou, Y. Immunotherapies targeting stimulatory pathways and beyond. J. Hematol. Oncol. 2021, 14, 78. [CrossRef]

54. Flood, B.A.; Higgs, E.F.; Li, S.; Luke, J.J.; Gajewski, T.F. STING pathway agonism as a cancer therapeutic. Immunol. Rev. 2019, 290, 24-38. [CrossRef] [PubMed]

55. Zhu, Y.; An, X.; Zhang, X.; Qiao, Y.; Zheng, T.; Li, X. STING: A master regulator in the cancer-immunity cycle. Mol. Cancer 2019, 18, 152. [CrossRef] [PubMed]

56. Meric-Bernstam, F.; Sandhu, S.K.; Hamid, O.; Spreafico, A.; Kasper, S.; Dummer, R.; Shimizu, T.; Steeghs, N.; Lewis, N.; Talluto, C.C.; et al. Phase Ib study of MIW815 (ADU-S100) in combination with spartalizumab (PDR001) in patients (pts) with advanced/metastatic solid tumors or lymphomas. J. Clin. Oncol. 2019, 37, 2507. [CrossRef]

57. Plieth, J. Chinook Marks an Ignominious End for Sting. Available online: https://www.evaluate.com/vantage/articles/news/ chinook-marks-ignominious-end-sting (accessed on 7 September 2021).

58. Harrington, K.J.; Brody, J.; Ingham, M.; Strauss, J.; Cemerski, S.; Wang, M.; Tse, A.; Khilnani, A.; Marabelle, A.; Golan, T. Preliminary results of the first-in-human (FIH) study of MK-1454, an agonist of stimulator of interferon genes (STING), as monotherapy or in combination with pembrolizumab (pembro) in patients with advanced solid tumors or lymphomas. Ann. Oncol. 2018, 29, viii712. [CrossRef]

59. Pan, B.S.; Perera, S.A.; Piesvaux, J.A.; Presland, J.P.; Schroeder, G.K.; Cumming, J.N.; Trotter, B.W.; Altman, M.D.; Buevich, A.V.; Cash, B.; et al. An orally available non-nucleotide STING agonist with antitumor activity. Science 2020, 369. [CrossRef] [PubMed]

60. Babiker, H.M.; Subbiah, V.; Ali, A.; Algazi, A.; Schachter, J.; Lotem, M.; Maurice-Dror, C.; Hendler, D.; Rahimian, S.; Minderman, H.; et al. Abstract CT134: Tilsotolimod engages the TLR9 pathway to promote antigen presentation and Type-I IFN signaling in solid tumors. Cancer Res. 2020, 80, CT134. [CrossRef]

61. Haymaker, C.; Andtbacka, R.H.; Johnson, D.B.; Shaheen, M.F.; Rahimian, S.; Chunduru, S.; Gabrail, N.; Doolittle, G.; Puzanov, I.; Markowitz, J.; et al. 1083MO-Final results from ILLUMINATE-204, a phase I/II trial of intratumoral tilsotolimod in combination with ipilimumab in PD-1 inhibitor refractory advanced melanoma. Ann. Oncol. 2020, 31, S672-S710. [CrossRef]

62. Idera Pharmaceuticals Announces Results from ILLUMINATE-301 Trial of Tilsotolimod and Ipilimumab in Anti-PD-1 Refractory Advanced Melanoma. Available online: https://ir.iderapharma.com/news-releases/news-release-details/iderapharmaceuticals-announces-results-illuminate-301-trial (accessed on 1 September 2021).

63. Ekeke, C.N.; Russell, K.L.; Joubert, K.; Bartlett, D.L.; Luketich, J.D.; Soloff, A.C.; Guo, Z.S.; Lotze, M.T.; Dhupar, R. Fighting Fire With Fire: Oncolytic Virotherapy for Thoracic Malignancies. Ann. Surg. Oncol. 2021, 28, 2715-2727. [CrossRef] [PubMed]

64. Haanen, J.B.A.G.; Califano, R.; Lugowska, I.; Garassino, M.C. (Eds.) ESMO Handbook of Immuno-Oncology; ESMO Press: Lugano, Switzerland, 2018.

65. Chen, C.Y.; Hutzen, B.; Wedekind, M.F.; Cripe, T.P. Oncolytic virus and PD-1/PD-L1 blockade combination therapy. Oncolytic Virother. 2018, 7, 65-77. [CrossRef] [PubMed]

66. Andtbacka, R.H.; Kaufman, H.L.; Collichio, F.; Amatruda, T.; Senzer, N.; Chesney, J.; Delman, K.A.; Spitler, L.E.; Puzanov, I.; Agarwala, S.S.; et al. Talimogene Laherparepvec Improves Durable Response Rate in Patients With Advanced Melanoma. J. Clin. Oncol. 2015, 33, 2780-2788. [CrossRef] [PubMed]

67. Andtbacka, R.H.I.; Collichio, F.; Harrington, K.J.; Middleton, M.R.; Downey, G.; Öhrling, K.; Kaufman, H.L. Final analyses of OPTiM: A randomized phase III trial of talimogene laherparepvec versus granulocyte-macrophage colony-stimulating factor in unresectable stage III-IV melanoma. J. Immunother. Cancer 2019, 7, 145. [CrossRef] [PubMed]

68. Chesney, J.; Puzanov, I.; Collichio, F.; Singh, P.; Milhem, M.M.; Glaspy, J.; Hamid, O.; Ross, M.; Friedlander, P.; Garbe, C.; et al Randomized, Open-Label Phase II Study Evaluating the Efficacy and Safety of Talimogene Laherparepvec in Combination With Ipilimumab Versus Ipilimumab Alone in Patients With Advanced, Unresectable Melanoma. J. Clin. Oncol. 2018, 36, $1658-1667$. [CrossRef] [PubMed]

69. Ribas, A.; Dummer, R.; Puzanov, I.; VanderWalde, A.; Andtbacka, R.H.I.; Michielin, O.; Olszanski, A.J.; Malvehy, J.; Cebon, J.; Fernandez, E.; et al. Oncolytic Virotherapy Promotes Intratumoral T Cell Infiltration and Improves Anti-PD-1 Immunotherapy. Cell 2017, 170, 1109-1119.e10. [CrossRef] [PubMed]

70. Transgene Reports on the Combination Trial of TG4010, Chemotherapy and Nivolumab in Non-Small Cell Lung Cancer. Available online: https:/ / www.businesswire.com/news/home/20191212005561/en/Transgene-Reports-on-the-Combination-Trial-ofTG4010-Chemotherapy-and-Nivolumab-in-Non-Small-Cell-Lung-Cancer (accessed on 2 September 2021).

71. Rudin, C.M.; Pandha, H.S.; Gupta, S.; Zibelman, M.R.; Akerley, W.; Day, D.; Hill, A.G.; Sanborn, R.E.; O'Day, S.J.; Clay, T.D.; et al. Phase Ib KEYNOTE-200: A study of an intravenously delivered oncolytic virus, coxsackievirus A21 in combination with pembrolizumab in advanced NSCLC and bladder cancer patients. Ann. Oncol. 2018, 29, viii732. [CrossRef]

72. Bentebibel, S.-E.; Hurwitz, M.E.; Bernatchez, C.; Haymaker, C.; Hudgens, C.W.; Kluger, H.M.; Tetzlaff, M.T.; Tagliaferri, M.A.; Zalevsky, J.; Hoch, U.; et al. A First-in-Human Study and Biomarker Analysis of NKTR-214, a Novel IL2R $\beta \gamma$-Biased Cytokine, in Patients with Advanced or Metastatic Solid Tumors. Cancer Discov. 2019, 9, 711-721. [CrossRef] [PubMed]

73. Boni, V.; Winer, I.S.; Gilbert, L.; Vaishampayan, U.N.; Rosen, S.D.; Muzaffar, J.; Spreafico, A.; McDermott, D.F.; Chu, Q.S.; Dumas, O.; et al. ARTISTRY-1: Nemvaleukin alfa monotherapy and in combination with pembrolizumab in patients (pts) with advanced solid tumors. J. Clin. Oncol. 2021, 39, 2513. [CrossRef] 
74. Diab, A.; Tannir, N.M.; Bentebibel, S.-E.; Hwu, P.; Papadimitrakopoulou, V.; Haymaker, C.; Kluger, H.M.; Gettinger, S.N.; Sznol, M.; Tykodi, S.S.; et al. Bempegaldesleukin (NKTR-214) plus Nivolumab in Patients with Advanced Solid Tumors: Phase I Dose-Escalation Study of Safety, Efficacy, and Immune Activation (PIVOT-02). Cancer Discov. 2020, 10, 1158-1173. [CrossRef] [PubMed]

75. Wrangle, J.M.; Awad, M.M.; Badin, F.B.; Rubinstein, M.P.; Bhar, P.; Garner, C.; Reddy, S.K.; Soon-Shiong, P. Preliminary data from QUILT 3.055: A phase 2 multi-cohort study of N803 (IL-15 superagonist) in combination with checkpoint inhibitors (CPI). J. Clin. Oncol. 2021, 39, 2596. [CrossRef]

76. Wrangle, J.M.; Velcheti, V.; Patel, M.R.; Garrett-Mayer, E.; Hill, E.G.; Ravenel, J.G.; Miller, J.S.; Farhad, M.; Anderton, K.; Lindsey, K.; et al. ALT-803, an IL-15 superagonist, in combination with nivolumab in patients with metastatic non-small cell lung cancer: A non-randomised, open-label, phase $1 \mathrm{~b}$ trial. Lancet Oncol. 2018, 19, 694-704. [CrossRef]

77. Ciardiello, D.; Elez, E.; Tabernero, J.; Seoane, J. Clinical development of therapies targeting TGF-beta: Current knowledge and future perspectives. Ann. Oncol. 2020, 31, 1336-1349. [CrossRef] [PubMed]

78. Soria, J.C.; Mauguen, A.; Reck, M.; Sandler, A.B.; Saijo, N.; Johnson, D.H.; Burcoveanu, D.; Fukuoka, M.; Besse, B.; Pignon, J.P. Systematic review and meta-analysis of randomised, phase II/III trials adding bevacizumab to platinum-based chemotherapy as first-line treatment in patients with advanced non-small-cell lung cancer. Ann. Oncol. 2013, 24, 20-30. [CrossRef] [PubMed]

79. Garon, E.B.; Ciuleanu, T.-E.; Arrieta, O.; Prabhash, K.; Syrigos, K.N.; Goksel, T.; Park, K.; Gorbunova, V.; Kowalyszyn, R.D.; Pikiel, J.; et al. Ramucirumab plus docetaxel versus placebo plus docetaxel for second-line treatment of stage IV non-small-cell lung cancer after disease progression on platinum-based therapy (REVEL): A multicentre, double-blind, randomised phase 3 trial. Lancet 2014, 384, 665-673. [CrossRef]

80. Reck, M.; Kaiser, R.; Mellemgaard, A.; Douillard, J.-Y.; Orlov, S.; Krzakowski, M.; von Pawel, J.; Gottfried, M.; Bondarenko, I.; Liao, M.; et al. Docetaxel plus nintedanib versus docetaxel plus placebo in patients with previously treated non-small-cell lung cancer (LUME-Lung 1): A phase 3, double-blind, randomised controlled trial. Lancet Oncol. 2014, 15, 143-155. [CrossRef]

81. Manegold, C.; Dingemans, A.-M.C.; Gray, J.E.; Nakagawa, K.; Nicolson, M.; Peters, S.; Reck, M.; Wu, Y.-L.; Brustugun, O.T.; Crinò, L.; et al. The Potential of Combined Immunotherapy and Antiangiogenesis for the Synergistic Treatment of Advanced NSCLC. J. Thorac. Oncol. 2017, 12, 194-207. [CrossRef]

82. Socinski, M.A.; Nishio, M.; Jotte, R.M.; Cappuzzo, F.; Orlandi, F.; Stroyakovskiy, D.; Nogami, N.; Rodríguez-Abreu, D.; Moro-Sibilot, D.; Thomas, C.A.; et al. IMpower150 Final Overall Survival Analyses for Atezolizumab Plus Bevacizumab and Chemotherapy in First-Line Metastatic Nonsquamous NSCLC. J. Thorac. Oncol. 2021, 16, 1909-1924. [CrossRef] [PubMed]

83. Tumeh, P.C.; Hellmann, M.D.; Hamid, O.; Tsai, K.K.; Loo, K.L.; Gubens, M.A.; Rosenblum, M.; Harview, C.L.; Taube, J.M.; Handley, N.; et al. Liver Metastasis and Treatment Outcome with Anti-PD-1 Monoclonal Antibody in Patients with Melanoma and NSCLC. Cancer Immunol. Res. 2017, 5, 417-424. [CrossRef] [PubMed]

84. Reck, M.; Mok, T.; Socinski, M.A.; Jotte, R.M.; Lim, D.W.T.; Cappuzzo, F.; Orlandi, F.J.; Stroyakovskiy, D.; Nogami, N.; RodriguezAbreu, D.; et al. 1293P IMpower150: Updated efficacy analysis in patients with EGFR mutations. Ann. Oncol. 2020, 31, S837-S838. [CrossRef]

85. Neal, J.W.; Lim, F.L.; Felip, E.; Gentzler, R.D.; Patel, S.B.; Baranda, J.; Fang, B.; Squillante, C.M.; Simonelli, M.; Werneke, S.; et al. Cabozantinib in combination with atezolizumab in non-small cell lung cancer (NSCLC) patients previously treated with an immune checkpoint inhibitor: Results from cohort 7 of the COSMIC-021 study. J. Clin. Oncol. 2020, 38, 9610. [CrossRef]

86. Gao, G.; Wang, Y.; Ren, S.; Zhao, J.; Chen, G.; Chen, J.; Gu, K.; Guo, R.; Pan, Y.; Wang, Q.; et al. 1267P Efficacy of camrelizumab (SHR-1210) plus apatinib as second-line treatment for advanced squamous NSCLC. Ann. Oncol. 2020, 31, S819. [CrossRef]

87. Zhou, C.; Gao, G.; Wang, Y.N.; Zhao, J.; Chen, G.; Liu, Z.; Gu, K.; Huang, M.; He, J.; Chen, J.; et al. Efficacy of PD-1 monoclonal antibody SHR-1210 plus apatinib in patients with advanced nonsquamous NSCLC with wild-type EGFR and ALK. J. Clin. Oncol. 2019, 37, 9112. [CrossRef]

88. Zhao, S.; Ren, S.; Jiang, T.; Zhu, B.; Li, X.; Zhao, C.; Jia, Y.; Shi, J.; Zhang, L.; Liu, X.; et al. Low-Dose Apatinib Optimizes Tumor Microenvironment and Potentiates Antitumor Effect of PD-1/PD-L1 Blockade in Lung Cancer. Cancer Immunol. Res. 2019, 7 , 630-643. [CrossRef] [PubMed]

89. Paz-Ares, L.; Kim, T.M.; Vicente, D.; Felip, E.; Lee, D.H.; Lee, K.H.; Lin, C.-C.; Flor, M.J.; Di Nicola, M.; Alvarez, R.M.; et al. Bintrafusp Alfa, a Bifunctional Fusion Protein Targeting TGF- $\beta$; and PD-L1, in Second-Line Treatment of Patients with NSCLC: Results From an Expansion Cohort of a Phase 1 Trial. J. Thorac. Oncol. 2020, 15, 1210-1222. [CrossRef] [PubMed]

90. Adams, B. GSK, German Merck's \$4.2B Bintrafusp Alfa Drug a Bust, Fails to Beat King Keytruda in Lung Cancer. Available online: https:/ / www.fiercebiotech.com/biotech/gsk-german-merck-s-4-2b-bintrafusp-alfa-drug-a-bust-fails-to-beat-kingkeytruda-lung-cancer (accessed on 15 September 2021).

91. Skoulidis, F.; Goldberg, M.E.; Greenawalt, D.M.; Hellmann, M.D.; Awad, M.M.; Gainor, J.F.; Schrock, A.B.; Hartmaier, R.J.; Trabucco, S.E.; Gay, L.; et al. STK11/LKB1 Mutations and PD-1 Inhibitor Resistance in KRAS-Mutant Lung Adenocarcinoma. Cancer Discov. 2018, 8, 822-835. [CrossRef]

92. Hong, D.S.; Fakih, M.G.; Strickler, J.H.; Desai, J.; Durm, G.A.; Shapiro, G.I.; Falchook, G.S.; Price, T.J.; Sacher, A.; Denlinger, C.S.; et al. KRASG12C Inhibition with Sotorasib in Advanced Solid Tumors. N. Engl. J. Med. 2020, 383, 1207-1217. [CrossRef]

93. Skoulidis, F.; Li, B.T.; Dy, G.K.; Price, T.J.; Falchook, G.S.; Wolf, J.; Italiano, A.; Schuler, M.; Borghaei, H.; Barlesi, F.; et al. Sotorasib for Lung Cancers with KRAS p.G12C Mutation. N. Engl. J. Med. 2021, 384, 2371-2381. [CrossRef] [PubMed]

94. Waldman, A.D.; Fritz, J.M.; Lenardo, M.J. A guide to cancer immunotherapy: From T cell basic science to clinical practice. Nat. Rev. Immunol. 2020, 20, 651-668. [CrossRef] [PubMed] 
95. Guedan, S.; Ruella, M.; June, C.H. Emerging Cellular Therapies for Cancer. Annu. Rev. Immunol. 2019, 37, 145-171. [CrossRef] [PubMed]

96. Rosenberg, S.A.; Yang, J.C.; Sherry, R.M.; Kammula, U.S.; Hughes, M.S.; Phan, G.Q.; Citrin, D.E.; Restifo, N.P.; Robbins, P.F.; Wunderlich, J.R.; et al. Durable complete responses in heavily pretreated patients with metastatic melanoma using T-cell transfer immunotherapy. Clin. Cancer Res. 2011, 17, 4550-4557. [CrossRef]

97. Creelan, B.C.; Wang, C.; Teer, J.K.; Toloza, E.M.; Yao, J.; Kim, S.; Landin, A.M.; Mullinax, J.E.; Saller, J.J.; Saltos, A.N.; et al. Tumor-infiltrating lymphocyte treatment for anti-PD-1-resistant metastatic lung cancer: A phase 1 trial. Nat. Med. 2021, 27, 1410-1418. [CrossRef] [PubMed]

98. June, C.H.; Sadelain, M. Chimeric Antigen Receptor Therapy. N. Engl. J. Med. 2018, 379, 64-73. [CrossRef] [PubMed]

99. Park, J.H.; Riviere, I.; Gonen, M.; Wang, X.; Senechal, B.; Curran, K.J.; Sauter, C.; Wang, Y.; Santomasso, B.; Mead, E.; et al. Long-Term Follow-up of CD19 CAR Therapy in Acute Lymphoblastic Leukemia. N. Engl. J. Med. 2018, 378, 449-459. [CrossRef] [PubMed]

100. Neelapu, S.S.; Locke, F.L.; Bartlett, N.L.; Lekakis, L.J.; Miklos, D.B.; Jacobson, C.A.; Braunschweig, I.; Oluwole, O.O.; Siddiqi, T.; Lin, Y.; et al. Axicabtagene Ciloleucel CAR T-Cell Therapy in Refractory Large B-Cell Lymphoma. N. Engl. J. Med. 2017, 377, 2531-2544. [CrossRef] [PubMed]

101. Rizvi, N.A.; Cho, B.C.; Reinmuth, N.; Lee, K.H.; Luft, A.; Ahn, M.-J.; van den Heuvel, M.M.; Cobo, M.; Vicente, D.; Smolin, A.; et al. Durvalumab With or Without Tremelimumab vs Standard Chemotherapy in First-line Treatment of Metastatic Non-Small Cell Lung Cancer: The MYSTIC Phase 3 Randomized Clinical Trial. JAMA Oncol. 2020, 6, 661-674. [CrossRef] [PubMed]

102. Update on the Phase III NEPTUNE Trial of Imfinzi plus Tremelimumab in Stage IV Non-Small Cell Lung Cancer. Available online: https:/ / www.astrazeneca.com/media-centre/press-releases/2019/update-on-the-phase-iii-neptune-trial-of-imfinziplus-tremelimumab-in-stage-iv-non-small-cell-lung-cancer-21082019.html\# (accessed on 4 September 2021).

103. Leighl, N.B.; Laurie, S.A.; Goss, G.D.; Hughes, B.G.M.; Stockler, M.R.; Tsao, M.S.; Kulkarni, S.; Blais, N.; Joy, A.A.; Mates, M.; et al. CCTG BR.34: A randomized trial of durvalumab and tremelimumab +/- platinum-based chemotherapy in patients with metastatic (Stage IV) squamous or nonsquamous non-small cell lung cancer (NSCLC). J. Clin. Oncol. 2020, 38, 9502. [CrossRef]

104. Johnson, M.; Cho, B.C.; Luft, A.; Alatorre-Alexander, J.; Geater, S.L.; Laktionov, K.; Vasiliev, A.; Trukhin, D.; Kim, S.; Ursol, G.; et al. Durvalumab \pm Tremelimumab + Chemotherapy as First-Line Treatment for mNSCLC: Results from the Phase 3 POSEIDON Study. Presented at: World Conference on Lung Cancer 2021. Available online: https://jamanetwork.com/journals/jamaoncology / fullarticle/2763864 (accessed on 15 September 2021).

105. Plieth, J. Sanofi does a spring clean. Available online: https://www.evaluate.com/vantage/articles/news/corporate-strategy/ sanofi-does-spring-clean (accessed on 5 September 2021).

106. Shim, B.Y.; Lee, S.; de Castro Carpeño, J.; Chiu, C.H.; Cobo, M.; Kim, H.R.; Ryu, J.S.; Tarruella, M.M.; Summers, Y.; Thomas, C.A.; et al. 1269P EMPOWER-lung 4: Phase II, randomized, open-label high dose or standard dose cemiplimab alone/plus ipilimumab in the second-line treatment of advanced non-small cell lung cancer (NSCLC). Ann. Oncol. 2020, 31, S820. [CrossRef]

107. Hellmann, M.D.; Rizvi, N.A.; Goldman, J.W.; Gettinger, S.N.; Borghaei, H.; Brahmer, J.R.; Ready, N.E.; Gerber, D.E.; Chow, L.Q.; Juergens, R.A.; et al. Nivolumab plus ipilimumab as first-line treatment for advanced non-small-cell lung cancer (CheckMate 012): Results of an open-label, phase 1, multicohort study. Lancet Oncol. 2017, 18, 31-41. [CrossRef]

108. Ready, N.; Hellmann, M.D.; Awad, M.M.; Otterson, G.A.; Gutierrez, M.; Gainor, J.F.; Borghaei, H.; Jolivet, J.; Horn, L.; Mates, M.; et al. First-Line Nivolumab Plus Ipilimumab in Advanced Non-Small-Cell Lung Cancer (CheckMate 568): Outcomes by Programmed Death Ligand 1 and Tumor Mutational Burden as Biomarkers. J. Clin. Oncol. 2019, 37, 992-1000. [CrossRef]

109. Coward, J.; Ganju, V.; Behzadigohar, R.; Kwong, K.; Xu, J.; Van, H.; Kong, P.; Yang, F.; Chen, L.; Guo, K.; et al. Preliminary safety, efficacy, and pharmacokinetics (PK) results of KN046 (bispecific anti-PD-L1/CTLA4) from a first-in-human study in subjects with advanced solid tumors. J. Clin. Oncol. 2019, 37, 2554. [CrossRef]

110. Berezhnoy, A.; Sumrow, B.J.; Stahl, K.; Shah, K.; Liu, D.; Li, J.; Hao, S.S.; De Costa, A.; Kaul, S.; Bendell, J.; et al. Development and Preliminary Clinical Activity of PD-1-Guided CTLA-4 Blocking Bispecific DART Molecule. Cell Rep. Med. 2020, 1, 100163. [CrossRef] [PubMed]

111. Perets, R.; Bar, J.; Rasco, D.W.; Ahn, M.J.; Yoh, K.; Kim, D.W.; Nagrial, A.; Satouchi, M.; Lee, D.H.; Spigel, D.R.; et al. Safety and efficacy of quavonlimab, a novel anti-CTLA-4 antibody (MK-1308), in combination with pembrolizumab in first-line advanced non-small-cell lung cancer. Ann. Oncol. 2021, 32, 395-403. [CrossRef] [PubMed]

112. Bendell, J.C.; Bedard, P.; Bang, Y.-J.; LoRusso, P.; Hodi, S.; Gordon, M.; D’Angelo, S.; D’Angelo, S.; Desai, J.; Garralda, E.; et al. Abstract CT302: Phase Ia/Ib dose-escalation study of the anti-TIGIT antibody tiragolumab as a single agent and in combination with atezolizumab in patients with advanced solid tumors. Cancer Res. 2020, 80, CT302. [CrossRef]

113. Johnson, M.L.; Patel, M.R.; Cherry, M.; Kang, Y.-K.; Yamaguchi, K.; Oh, D.-Y.; Hussein, M.A.; Kitano, S.; Kondo, S.; Hansen, A.R.; et al. Safety of BI 754111, an anti-LAG-3 monoclonal antibody (mAb), in combination with BI 754091, an anti-PD-1 mAb, in patients with advanced solid tumors. J. Clin. Oncol. 2020, 38, 3063. [CrossRef]

114. Hong, D.S.; Schoffski, P.; Calvo, A.; Sarantopoulos, J.; Olza, M.O.D.; Carvajal, R.D.; Prawira, A.; Kyi, C.; Esaki, T.; Akerley, W.L.; et al. Phase I/II study of LAG525 \pm spartalizumab (PDR001) in patients (pts) with advanced malignancies. J. Clin. Oncol. 2018, 36, 3012. [CrossRef] 
115. Papadopoulos, K.P.; Lakhani, N.J.; Johnson, M.L.; Park, H.; Wang, D.; Yap, T.A.; Dowlati, A.; Maki, R.G.; Lynce, F.; Ulahannan, S.V.; et al. First-in-human study of REGN3767 (R3767), a human LAG-3 monoclonal antibody (mAb), \pm cemiplimab in patients (pts) with advanced malignancies. J. Clin. Oncol. 2019, 37, 2508. [CrossRef]

116. Ascierto, P.A.; Bono, P.; Bhatia, S.; Melero, I.; Nyakas, M.S.; Svane, I.M.; Larkin, J.; Gomez-Roca, C.; Schadendorf, D.; Dummer, R.; et al. Efficacy of BMS-986016, a monoclonal antibody that targets lymphocyte activation gene-3 (LAG-3), in combination with nivolumab in pts with melanoma who progressed during prior anti-PD-1/PD-L1 therapy (mel prior IO) in all-comer and biomarker-enriched populations. Ann. Oncol. 2017, 28, v611-v612. [CrossRef]

117. Luke, J.J.; Patel, M.R.; Hamilton, E.P.; Chmielowski, B.; Ulahannan, S.V.; Kindler, H.L.; Bahadur, S.W.; Clingan, P.R.; Mallesara, G.; Weickhardt, A.J.; et al. A phase I, first-in-human, open-label, dose-escalation study of MGD013, a bispecific DART molecule binding PD-1 and LAG-3, in patients with unresectable or metastatic neoplasms. J. Clin. Oncol. 2020, 38, 3004. [CrossRef]

118. Harding, J.J.; Patnaik, A.; Moreno, V.; Stein, M.; Jankowska, A.M.; Mendizabal, N.V.d.; Liu, Z.T.; Koneru, M.; Calvo, E. A phase $\mathrm{Ia} / \mathrm{Ib}$ study of an anti-TIM-3 antibody (LY3321367) monotherapy or in combination with an anti-PD-L1 antibody (LY3300054): Interim safety, efficacy, and pharmacokinetic findings in advanced cancers. J. Clin. Oncol. 2019, 37, 12. [CrossRef]

119. Curigliano, G.; Gelderblom, H.; Mach, N.; Doi, T.; Tai, W.M.D.; Forde, P.; Sarantopoulos, J.; Bedard, P.L.; Lin, C.-C.; Hodi, S.; et al. Abstract CT183: Phase (Ph) I/II study of MBG453 \pm spartalizumab (PDR001) in patients (pts) with advanced malignancies. Cancer Res. 2019, 79, CT183. [CrossRef]

120. Doi, T.; Fujiwara, Y.; Shitara, K.; Shimizu, T.; Yonemori, K.; Matsubara, N.; Ohno, I.; Kogawa, T.; Naito, Y.; Leopold, L.; et al. The safety and tolerability of epacadostat alone and in combination with pembrolizumab in patients with advanced solid tumors: Results from a first-in-Japanese phase I study (KEYNOTE-434). Investig. New Drugs 2021, 39, 152-162. [CrossRef] [PubMed]

121. Hellmann, M.D.; Gettinger, S.; Chow, L.Q.M.; Gordon, M.; Awad, M.M.; Cha, E.; Gong, X.; Zhou, G.; Walker, C.; Leopold, L.; et al. Phase 1 study of epacadostat in combination with atezolizumab for patients with previously treated advanced nonsmall cell lung cancer. Int. J. Cancer 2020, 147, 1963-1969. [CrossRef] [PubMed]

122. Mitchell, T.C.; Hamid, O.; Smith, D.C.; Bauer, T.M.; Wasser, J.S.; Olszanski, A.J.; Luke, J.J.; Balmanoukian, A.S.; Schmidt, E.V.; Zhao, Y.; et al. Epacadostat Plus Pembrolizumab in Patients With Advanced Solid Tumors: Phase I Results From a Multicenter, Open-Label Phase I/II Trial (ECHO-202/KEYNOTE-037). J. Clin. Oncol. 2018, 36, 3223-3230. [CrossRef] [PubMed]

123. Plieth, J.; Armstrong, M. Incyte's Epacadostat Blow-Up Leaves a Trail of Destruction. Available online: https://www.evaluate. $\mathrm{com} /$ vantage/articles/news/incytes-epacadostat-blow-leaves-trail-destruction (accessed on 6 September 2021).

124. Jung, K.H.; LoRusso, P.; Burris, H.; Gordon, M.; Bang, Y.-J.; Hellmann, M.D.; Cervantes, A.; Ochoa de Olza, M.; Marabelle, A.; Hodi, F.S.; et al. Phase I Study of the Indoleamine 2,3-Dioxygenase 1 (IDO1) Inhibitor Navoximod (GDC-0919) Administered with PD-L1 Inhibitor (Atezolizumab) in Advanced Solid Tumors. Clin. Cancer Res. 2019, 25, 3220-3228. [CrossRef] [PubMed]

125. Infante, J.R.; Hansen, A.R.; Pishvaian, M.J.; Chow, L.Q.M.; McArthur, G.A.; Bauer, T.M.; Liu, S.V.; Sandhu, S.K.; Tsai, F.Y.-C.; Kim, J.; et al. A phase Ib dose escalation study of the OX40 agonist MOXR0916 and the PD-L1 inhibitor atezolizumab in patients with advanced solid tumors. J. Clin. Oncol. 2016, 34, 101. [CrossRef]

126. Massarelli, E.; Balmanoukian, A.S.; Vieito, M.; Tourneau, C.L.; Hernandez-Guerrero, T.; Trigo, J.M.; Aljumaily, R.; Chisamore, M.J.; Rogan, D.; Sung, R.; et al. INDUCE-1: Report on safety run-in cohorts combining Inducible T-cell co-stimulatory receptor (ICOS) agonist GSK3359609 (GSK609) with platinum+5-FU chemotherapy (5-FU/plat), with or without pembrolizumab (PE), for the treatment of advanced solid tumors. J. Clin. Oncol. 2020, 38, 6544. [CrossRef]

127. Formenti, S.C.; Rudqvist, N.P.; Golden, E.; Cooper, B.; Wennerberg, E.; Lhuillier, C.; Vanpouille-Box, C.; Friedman, K.; Ferrari de Andrade, L.; Wucherpfennig, K.W.; et al. Radiotherapy induces responses of lung cancer to CTLA-4 blockade. Nat. Med. 2018, 24 , 1845-1851. [CrossRef] [PubMed]

128. Bozorgmehr, F.; Fischer, J.R.; Bischof, M.; Atmaca, A.; Wetzel, S.; Faehling, M.; Bottke, D.; Wermke, M.; Troost, E.G.C.; SchmidtkeSchrezenmeier, G.; et al. LBA58 ORR in patients receiving nivolumab plus radiotherapy in advanced non-small cell lung cancer: First results from the FORCE trial. Ann. Oncol. 2020, 31, S1187. [CrossRef]

129. Tang, C.; Welsh, J.W.; de Groot, P.; Massarelli, E.; Chang, J.Y.; Hess, K.R.; Basu, S.; Curran, M.A.; Cabanillas, M.E.; Subbiah, V.; et al. Ipilimumab with Stereotactic Ablative Radiation Therapy: Phase I Results and Immunologic Correlates from Peripheral T Cells. Clin. Cancer Res. 2017, 23, 1388-1396. [CrossRef]

130. Jacob, A.; Kreimer, A.; Wei, J.; Wu, J.; Corum, L.; Reusch, E.; Woodward, J.; Cohen, D.; Bondada, S.; Adams, V.R.; et al. Priming immunotherapy with radiotherapy (RT) in advanced non-small cell lung cancer (NSCLC) and head and neck squamous cell cancer (HNSCC): Interim analysis of phase II clinical trial. J. Clin. Oncol. 2021, 39, 2628. [CrossRef]

131. Bassetti, M.F.; Sethakorn, N.; Lang, J.M.; Schehr, J.L.; Schultz, Z.; Morris, Z.S.; Matkowskyj, K.A.; Eickhoff, J.C.; Morris, B.; Traynor, A.M.; et al. Outcomes and safety analysis of a phase IB trial of stereotactic body radiotherapy (SBRT) to all sites of oligometastatic non-small cell lung cancer combined with durvalumab and tremelimumab. J. Clin. Oncol. 2021, 39, e21212. [CrossRef]

132. Lin, J.; Hoffman-Censits, J.H.; Kelly, W.K.; Tuluc, M.; Shaw, C.; Philipose, S.; Leiby, B.E.; Louie, J.; Harshyne, L.; Kean, R.; et al. An exploratory study to investigate the immunomodulatory activity of radiation therapy in combination with pembrolizumab in patients with renal cell cancer. J. Clin. Oncol. 2017, 35, e16058. [CrossRef]

133. Patel, M.R.; Tolcher, A.W.; Rasco, D.W.; Johnson, M.L.; Alistar, A.T.; Li, L.; Chung, A.H.; Andtbacka, R.H.I. BDB001, an intravenously administered toll-like receptor 7 and 8 (TLR7/8) agonist, in combination with pembrolizumab in advanced solid tumors: Phase 1 safety and efficacy results. J. Clin. Oncol. 2021, 39, 2512. [CrossRef] 
134. Garon, E.B.; Spira, A.I.; Johnson, M.; Bazhenova, L.; Leach, J.; Cummings, A.L.; Candia, A.; Coffman, R.L.; Janatpour, M.J.; Janssen, R.; et al. A Phase Ib Open-Label, Multicenter Study of Inhaled DV281, a TLR9 Agonist, in Combination with Nivolumab in Patients with Advanced or Metastatic Non-small Cell Lung Cancer. Clin. Cancer Res. 2021, 27, 4566-4573. [CrossRef] [PubMed]

135. Curigliano, G.; Jimenez, M.M.; Shimizu, T.; Keam, B.; Meric-Bernstam, F.; Rutten, A.; Glaspy, J.; Parikh, N.S.; Ising, M.; Hassounah, N.; et al. Abstract CT103: Phase I study of LHC165 \pm spartalizumab (PDR001) in patients (pts) with advanced solid tumors. Cancer Res. 2021, 81, CT103. [CrossRef]

136. Siu, L.; Brody, J.; Gupta, S.; Marabelle, A.; Jimeno, A.; Munster, P.; Grilley-Olson, J.; Rook, A.H.; Hollebecque, A.; Wong, R.K.S.; et al. Safety and clinical activity of intratumoral MEDI9197 alone and in combination with durvalumab and/or palliative radiation therapy in patients with advanced solid tumors. J. ImmunoTher. Cancer 2020, 8, e001095. [CrossRef]

137. Merchan, J.R.; Patel, M.; Cripe, T.P.; Old, M.O.; Strauss, J.F.; Thomassen, A.; Diaz, R.M.; Peng, K.W.; Russell, S.J.; Russell, L.; et al. Relationship of infusion duration to safety, efficacy, and pharmacodynamics (PD): Second part of a phase I-II study using VSV-IFN $\beta$-NIS (VV1) oncolytic virus in patients with refractory solid tumors. J. Clin. Oncol. 2020, 38, 3090. [CrossRef]

138. Galffy, G.; Lugowska, I.; Poddubskaya, E.; Cho, B.C.; Ahn, M.-J.; Han, J.-Y.; Su, W.-C.; Hauke, R.; Dyar, S.; Lee, D.H.; et al. 281 JAVELIN Medley VEGF: Phase 2 study of avelumab + axitinib in patients with previously treated non-small cell lung cancer (NSCLC) or treatment naive, cisplatin-ineligible urothelial cancer (UC). J. ImmunoTher. Cancer 2020, 8, A171-A172. [CrossRef]

139. Solomon, B.; Callejo, A.; Bar, J.; Berchem, G.; Bazhenova, L.; Saintigny, P.; Raymond, E.; Girard, N.; Sulaiman, R.; Bresson, C.; et al. 1574P—Survival prolongation by rationale innovative genomics (SPRING): An international WIN consortium phase I study exploring safety and efficacy of avelumab, palbociclib, and axitinib in advanced non-small cell lung cancer (NSCLC) with integrated genomic and transcriptomic correlates. Ann. Oncol. 2019, 30, v648. [CrossRef]

140. Ardeshir-Larijani, F.; Althouse, S.K.; Leal, T.; Feldman, L.E.; Hejleh, T.A.; Patel, M.; Gentzler, R.D.; Miller, A.R.; Hanna, N.H. Phase II trial of atezolizumab (A) + carboplatin (C) + pemetrexed (P) + bevacizumab (B) in pts with stage IV non-squamous non-small cell lung cancer (NSq-NSCLC): Big Ten Cancer Research Consortium Study LUN 17-139. J. Clin. Oncol. 2021, 39, 9034. [CrossRef]

141. Nishio, M.; Peled, N.; Zer, A.; Houghton, B.; Bar, J.; Drew, D.; Herbst, R.; Rodriguez-Abreu, D.; Talpur, R.; Golden, L.; et al. 1313P Phase III LEAP-006 safety run-in (Part 1): 1L pembrolizumab (Pembro) + chemotherapy (Chemo) with lenvatinib (Len) for metastatic NSCLC. Ann. Oncol. 2020, 31, S848-S849. [CrossRef]

142. Bang, Y.-J.; Golan, T.; Lin, C.-C.; Dahan, L.; Fu, S.; Moreno, V.; Geva, R.; Reck, M.; Wasserstrom, H.A.; Mi, G.; et al. Ramucirumab (Ram) and durvalumab (Durva) treatment of metastatic non-small cell lung cancer (NSCLC), gastric/gastroesophageal junction (G/GEJ) adenocarcinoma, and hepatocellular carcinoma (HCC) following progression on systemic treatment(s). J. Clin. Oncol. 2019, 37, 2528. [CrossRef]

143. Herbst, R.S.; Arkenau, H.T.; Santana-Davila, R.; Calvo, E.; Paz-Ares, L.; Cassier, P.A.; Bendell, J.; Penel, N.; Krebs, M.G.; MartinLiberal, J.; et al. Ramucirumab plus pembrolizumab in patients with previously treated advanced non-small-cell lung cancer, gastro-oesophageal cancer, or urothelial carcinomas (JVDF): A multicohort, non-randomised, open-label, phase 1a/b trial. Lancet Oncol. 2019, 20, 1109-1123. [CrossRef]

144. Herbst, R.S.; Arkenau, H.T.; Bendell, J.; Arrowsmith, E.; Wermke, M.; Soriano, A.; Penel, N.; Santana-Davila, R.; Bischoff, H.; Chau, I.; et al. Phase 1 Expansion Cohort of Ramucirumab Plus Pembrolizumab in Advanced Treatment-Naive NSCLC. J. Thorac. Oncol. 2021, 16, 289-298. [CrossRef] [PubMed]

145. Tsimberidou, A.; Guenther, K.; Alpert, A.; Andersson, B.; Coughlin, Z.; Fritsche, J.; Hilf, N.; Hwu, P.; Kalra, M.; Kuttruff-Coqui, S.; et al. 293 Resultsof the first-in-human clinical trial with personalized multi-target adoptive cell therapy (ACTolog IMA101). J. ImmunoTher. Cancer 2020, 8, A179. [CrossRef]

146. Kverneland, A.H.; Borch, T.H.; Chamberlain, C.; Lorentzen, C.L.; Nielsen, M.; Kjeldsen, J.W.; Moerk, S.K.; Donia, M.; Svane, I.M. 1022MO Clinical potential of adoptive cell therapy with tumour infiltrating lymphocytes therapy in combination with checkpoint inhibitors in non-melanoma patients. Ann. Oncol. 2020, 31, S706. [CrossRef] 